\title{
Collection Efficiency and Ice Accretion Calculations for a Boeing 737-300 Inlet
}

Colin S. Bidwell

Lewis Research Center

Cleveland, Ohio

Prepared for the

World Aviation Congress

cosponsored by the Society of Automotive Engineers and the American Institute for Aeronautics and Astronautics

Los Angeles, California, October 22-24, 1996

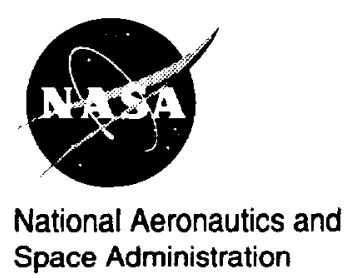





\title{
Collection Efficiency and Ice Accretion Calculations for a Boeing 737-300 Inlet
}

\author{
Colin S. Bidwell \\ National Aeronautics and Space Administration \\ Lewis Research Center \\ Cleveland, Ohio 44135
}

\section{SUMMARY}

Collection efficiency and ice accretion calculations have been made for a Boeing 737-300 inlet using a three-dimensional panel code, an adaptive grid code, the NASA Lewis LEWICE3D grid based ice accretion code. Flow solutions for the inlet were generated using the VSAERO panel code. Grids used in the ice accretion calculations were generated using the newly developed adaptive grid code ICEGRID3D. The LEWICE3D grid based ice accretion program was used to calculate impingement efficiency and ice shapes. Ice shapes typifying rime and mixed icing conditions were generated for a 30 minute hold condition. All calculations were performed on an SGI Power Challenge computer. The results have been compared to experimental flow and impingement data. In general, the calculated flow and collection efficiencies compared well with experiment, and the ice shapes looked reasonable and appeared representative of the rime and mixed icing conditions for which they were calculated.

\section{NOMENCLATURE}

\author{
d Droplet diameter, $\mu \mathrm{m}$ \\ HTC Convective heat transfer coefficient, $\mathrm{W} / \mathrm{m}^{2} / \mathrm{K}$ \\ LWC Liquid Water Content, $\mathrm{g} / \mathrm{m}^{3}$ \\ MVD Median Volume Diameter, $\mu \mathrm{m}$ \\ W Mass flow, $\mathrm{kg} / \mathrm{s}$ \\ $\beta \quad$ Collection efficiency \\ $\alpha \quad$ Angle-of-attack, degrees \\ $\theta \quad$ Radial angle around inlet lip measured from the upper inlet lip, degrees
}




\section{INTRODUCTION}

The last 15 years has brought great changes in the computer software and hardware industry, changes which have given the design engineer a larger more sophisticated set of tools. A literal explosion of software has effected every level and aspect of engineering design. Engineers now have quick, and accurate tools at their fingertips to handle just about any design task imaginable. Tasks that were once unmanageable or manageable only by small Computational Fluid Dynamic (CFD) groups on expensive machines are now tractable by the ordinary design engineer. Computer programs that once took 10 hours of computer time and 2 days of turnaround time can now be done overnight on powerful, inexpensive workstations. Design tasks that were once empirically based "arts" are now analytically based sciences. One such area that has benefitted greatly from these changes has been the design of aircraft ice protection systems.

The task of aircraft ice protection system design which was previously one of subjectivity, based heavily on correlation and extrapolation, and carried out by highly experienced individuals is now one of objectivity, based on sound models and carried out by entry level engineers. Historically systems have been designed using the methods of ADS-4 (ref. 1). This entailed interpolation or extrapolating from previously tested conditions and configurations. If a configuration or condition didn't exist in ADS-4 then various forms of extrapolation were used. As the aircraft industry progressed the newer designs were less and less similar to those in the ADS-4 database and the task of interpolation or extrapolation became harder and riskier. With the advent of the computer age numerical methods were made available, reducing the guess work. Many 2D and some 3D methods are now available to aid the user in designing an aircraft ice protection system (ref. 2-6). This paper outlines one such 3D method and presents validation for a Boeing 737-300 inlet.

Flow, trajectory and ice accretion calculations were made and compared to experiment for the Boeing 737-300 inlet using the VSAERO flow solver (ref. 7), the 3D adaptive grid code ICEGRID3D and the grid based NASA Lewis 3D ice accretion code LEWICE3D (ref. 6). The cases were chosen to illustrate the flexibility and to provide validation for the computer code.

The grid based LEWICE3D code is very similar to the panel based version and incorporates the same trajectory and ice accretion methodology. The codes are different, in that the grid based code does not incorporate a flow solver but is dependent on the user to supply one. Several advantages of this are the ability to handle a users particular flow solver and the fact that the grid based trajectory codes are significantly faster than the panel based trajectory codes. The code can handle generic multi-block, structured or unstructured grids, simple cartesian grids and adaptive grids with symmetry planes. Performance differences can be as high 200 to 1 between the panel and grid based methods with a typical grid based case (single section of interest, single drop size) taking about 2.5 minutes on an SGI Power Challenge computer.

Computational and experimental results are presented for flow, and collection efficiency for a Boeing 737-300 inlet. All of the flow calculations were made using the VSAERO flow solver. All of the aerodynamic and collection efficiency data were taken in 1985 in the NASA 
Lewis Icing Research Tunnel (IRT) under a program funded by NASA and the FAA and carried out by Wichita State University, Boeing Military Airplanes and NASA (ref. 8).

\section{EXPERIMENT}

\section{A. EXPERIMENTAL APPARATUS}

The aerodynamic and impingement efficiency tests were carried out in the NASA Lewis IRT. The test equipment included the IRT (fig. 1), the ESCORT data system, a special spray system for the impingement tests (fig. 2), a laser reflectometer for impingement efficiency data reduction (fig. 3), and the Boeing 737-300 inlet model (fig. 4).

The IRT facility can provide a range of airspeeds, angles-of-attack, temperatures, liquid water contents (LWC), and drop sizes (ref. 9). The IRT has a $2.47 \mathrm{~m} \times 1.82 \mathrm{~m}$ test section with a maximum airspeed of $134 \mathrm{~m} / \mathrm{s}$ (empty tunnel). Angle-of-attack is controlled by a movable turntable to which the models are mounted. A refrigeration system allows year-round testing at temperatures from $-29^{\circ} \mathrm{C}$ to $10^{\circ} \mathrm{C}$. The spray system located upstream of the test section can provide a cloud with a range of LWC of .25-3.0 gm/ $\mathrm{m}^{3}$ and a median volume drop (MVD) size range of 12 $40 \mu \mathrm{m}$.

The Escort system was developed at Lewis to aid in storage, processing, and analysis of large amounts of data (e.g. temperature, pressure) produced in various experiments at Lewis Research Center. In this test Escort was used to store tunnel total temperature, total pressure, free stream airspeed, surface pressure, produce real time calculations and display pertinent parameters. The storage sequence for each data point was initiated by the researcher in the control room. A separate program was used to do a more complete post run analysis.

The spray requirements for the impingement tests precipitated the need for a different spray system (fig. 2) than was available in the IRT (ref. 8). The IRT spray system could not produce the short (2-5 seconds), stable sprays (i.e. constant LWC and drop size) required to prevent blotter strip saturation. There were also concerns that the dye would contaminate the IRT spray system. The new system consisted of 12 nozzles and a supply tank located at the IRT spray bar station (fig. 2). The system featured short supply lines which enabled short, stable sprays.

One unique feature of the current technique is the laser reflectometer used to determine the local collection efficiency (fig. 3). The device measures the local reflectance of the blotter strip and correlates this to the local collection efficiency (ref. 8). The device saved considerable time in the data reduction of the blotter strips.

The Boeing 737-300 inlet model (fig. 4) was .2547 scale and had a conical centerbody. The model was provided by Boeing Commercial Airplane Company. The Boeing 737-300 was outfitted with 88 static pressure taps. The taps were located along 5 radial cuts: $\theta=0^{\circ}, 45^{\circ}, 90^{\circ}$, $135^{\circ}$ and $180^{\circ}$ (fig. 5). 


\section{B. EXPERIMENTAL TESTING}

Two types of testing were done in the IRT: aeroperformance and impingement efficiency testing. The aero-performance testing involved taking surface pressure measurements. The impingement efficiency testing involved the use of a dye tracer technique to measure the location and amount of water impinging on the model.

Surface pressures were measured on the inlet models using the ESCORT system. Pressure measurements were taken at an airspeed of $77 \mathrm{~m} / \mathrm{s}$, at angles-of-attack of $0^{\circ}$ and $15^{\circ}$ and inlet mass flows of $7.8 \mathrm{~kg} / \mathrm{s}$ and $10.4 \mathrm{~kg} / \mathrm{s}$ with the spray system off. Three sets of pressure measurements were taken for each configuration to establish repeatability of the data. These pressure measurements were used to generate surface Mach numbers for the comparisons presented in this paper.

The experimental technique used in the current tests to determine the impingement characteristics of a body is one that was developed on the early 1950's with a few modifications (ref. 8). The technique involved spraying a dye-water solution of a known concentration onto a model covered with blotter strips. Figure 6 shows a typical blotter installation for the 737-300 inlet. The result was that the local impingement efficiency rate was reflected on the blotter strips as a variation in color intensity. That is, the areas of higher impingement rate are darker and those with lower impingement rate are lighter.

Several steps were necessary to prepare the IRT for impingement testing. The specially designed spray system had to be installed and adjusted to produce a uniform cloud. The local LWC had to measured at each blotter strip location (with the tunnel empty) for every spray and tunnel condition to account for any cloud nonuniformity that existed after the final spray adjustment. After these adjustments and measurements were made the model was inserted and tested. Each points was repeated five times to obtain a statistical average (ref. 8).

A typical test point for involved several steps. The model was cleaned and blotter strips were attached at points of interest. Figure 6 shows a typical blotter strip installation for the 737300 inlet and illustrates the angular reference system used in presenting the data.The spray was then made, the blotter strips were removed, and labeled, and the model was cleaned and made ready for the next condition.

The Boeing 737-300 inlet model was tested for two drop sizes $(16.45 \mu \mathrm{m}, 20.36 \mu \mathrm{m})$, at two angles-of-attack $\left(0^{\circ}, 15^{\circ}\right)$ and at two mass flows $(7.8 \mathrm{~kg} / \mathrm{s}, 10.4 \mathrm{~kg} / \mathrm{s})$. The drop size tests were repeated three times for each condition to generate a statistical average. This resulted in a large amount of data ( 216 strips).

\section{ANALYTICAL METHOD}

The icing calculation required a three step process. All of the calculations were made on a a single SGI Power Challenge computer processor (R8000). The ICEGRID3D code was used to generate the grid for the trajectory calculations. The VSAERO code was used to generate the 
velocities on this grid and to generate the surface velocities needed in the LEWICE3D code. The LEWICE3D code then used the panel model the surface velocity information and the grid to make the ice accretion calculations. The LEWICE3D panel based computer program has been used in previous calculations of isolated, finite wings and full aircraft (ref. 10-14). The work presented here represents the first calculations made using the adaptive grid code (ICEGRID3D).

\section{A. ICEGRID3D}

The ICEGRID3D was developed at Lewis Research Center by Bidwell and Coirier specifically for the task of optimizing trajectory calculations in the LEWICE3D code. The program automatically produces grids which are optimal for trajectory calculations hence reducing the required effort to produce a "good" trajectory grid. The program also produces a minimum of grid points which reduces the panel code calculation times. The program requires the surface geometry and an input file describing the grid volume and refinement parameters. The code refines the grid near regions of interest which can include the geometry, parts of the geometry, and lines or points input by the user. The code is similar to an oct-tree method (ref. 15) in that it recursively divides the original grid volume until the refinement criteria for each cell has been met. The code will not refine cells internal to the geometry. The code is different from most oct-tree methods in that the grid volume is allowed to be multiply skewed, multiblock and different refinement functions can be used in any direction. This last feature is where the code really differs from the oct-tree methods in that it allows a given cell to be divided into 8,4 or 2 cells depending on the refinement function instead of the oct-tree method which divides a cell into 8 cells if the refinement is required. This results in grids with much fewer cells for cases where gridding requirements are disparate in the different directions (e.g. swept wings which have a much smaller cell size requirement in the chordwise direction than in the spanwise direction).

The grid used in the icing calculations is shown in figure 5. The grid contains 138,098 cells and 160,047 points. The grid plane at $y=0$ shows the major features of the grid. Two refinement functions were chosen for the grid in each direction. The first refinement function was based on distance from the surface. The user specifies a minimum cell size near the surface, the geometric rate of growth of the cell size as the distance from the body increases, and the maximum cell size far away from the body. Because of the highly 3D nature of the inlet and the fact that trajectory calculations were required everywhere, the refinement parameters in the $x, y$, and $z$ directions were set to be the same. The minimum $x, y$, and $z$ cell size near the surface was set to $2.54 \mathrm{~cm}$. The geometric growth rate of the cells was chosen to be 1.4. The maximum $x, y$, and $z$ cell size far from the body was chosen to be $12.7 \mathrm{~cm}$. The second refinement function was based on distance from the leading edge of the inlet. This area is where most of the trajectories were to be calculated and where the velocity gradients were the highest, hence, smaller grid spacing was required. As for the first function, the user specifies a minimum cell size near the surface, the geometric rate of growth of the cell size as the distance from the body increases, and the maximum cell size far away from the body. Additionally, the user specifies the region of panels on the surface for which the refinement is to be applied (i.e. the range of panel columns and rows of the surface patch). The minimum $x, y$, and $z$ cell size near the surface was set to $1.27 \mathrm{~cm}$. The geometric growth rate of the cells was chosen to be 1.4. The maximum $\mathrm{x}, \mathrm{y}$, and $\mathrm{z}$ cell size far from the body was chosen to be $12.7 \mathrm{~cm}$. It took approximately 5 hours of CPU time to generate this grid. 


\section{B. VSAERO}

VSAERO is a first order 3D potential flow panel code (ref. 7). Geometries are represented as quadrilaterals which have constant doublet and source distribution. The formulation used in VSAERO results in a solution that is second order accurate allowing for accurate flow solutions with fewer panels and less CPU time than other first order methods. The disadvantage of this method is that because a numerical differentiation is used to generate the velocity distribution careful panelling is required to prevent numerical errors. The code can generate solutions for internal and external compressible flows and can handle very large problems $(\sim 10,000$ panels $)$.

For the current study, VSAERO was run using a steady, isolated inlet flow with a $y=0$ plane of symmetry (fig. 4,5). The inlet model contained 1,692 panels. Flow solutions were run for two angles-of-attack $\left(0^{\circ}, 15^{\circ}\right)$ at two mass flows $(7.8 \mathrm{~kg} / \mathrm{s}$ and $10.2 \mathrm{~kg} / \mathrm{s})$. The flows solutions and velocity calculations took approximately 85 minutes for each of the cases.

\section{LEWICE3D}

The LEWICE3D grid based code incorporates trajectory, heat transfer and ice shape calculation into a single computer program. The code can handle generic multiblock structured grid based flow solutions, unstructured grid based flow solutions, simple cartesian grids with surface patches, and adaptive grids with surface patches. The latter two methods allow the use of generic panel code input which is a computationally efficient method for generating ice shapes. The code can handle overlapping and internal grids and can handle multiple planes of symmetry. Calculations of arbitrary streamlines and trajectories are possible. The code has the capability to calculate tangent trajectories and impingement efficiencies for single droplets or droplet distributions. Ice accretions can be calculated at arbitrary regions of interest in either a surface normal or tangent trajectory direction.

The methodology used in the LEWICE3D (ref. 6) analysis can be broken into six basic steps for each section of interest at each time step. In the first step, the flow field is generated by the user. Secondly, surface streamlines are calculated. The surface streamline analysis uses a variable step size fourth-order Runge-Kutta integration scheme developed by Bidwell (ref. 6). Thirdly, tangent trajectories are calculated at the region of interest. An array of particles is released between the tangent trajectories in the fourth step. These impacting particles are used to calculate collection efficiency as a function of surface position. The trajectory analysis is basically that of Hillyer Norment (ref. 16) with modifications by Bidwell (ref. 6). At the heart of the trajectory analysis is the variable step predictor-corrector integration scheme by Krogh (ref. 17). The fifth step involves interpolating or extrapolating the collection efficiencies onto the streamlines. In the sixth step the ice accretion for the streamline is calculated. The ice accretion model is basically that of the LEWICE2D code applied along surface streamlines (ref. 3).

LEWICE3D calculation times varied for the different cases depending upon the drop size and the number of trajectories. The LEWICE3D calculation times are heavily dependent upon grid size and structure because the largest portion of the LEWICE3D calculation time (greater than $99 \%$ ) is spent calculating velocities at specified points, which involves searching through the grid tree structure for the cell in which the point is located. The trajectory integration time for the 
cases varied from .2-.5 seconds. Approximately 100 trajectories were required for each drop size at each section-of-interest for the ice accretion calculations. This resulted in calculation times of approximately 1000 seconds for the inlet cases ( 5 sections-of-interest, 7 bin distribution). The collection efficiency calculations for the entire inlet depicted in figures 9-12 required quite a few more trajectories. A $200 \times 400$ matrix of particles was released for each drop size in the distribution. For each case then 560,000 trajectories were calculated resulting in run times of about 40 hours.

\section{ANALYSIS}

Surface velocity, heat transfer, collection efficiency, and ice shapes results are presented for the Boeing 737-300 inlet. Ice shape calculations were made for two icing conditions simulating a rime and a mixed condition. Comparisons to experimental collection efficiency are made for all of the cases and to experimental surface mach number or coefficient of pressure where available. Discussions of the icing conditions chosen, the LEWICE3D program parameters used, and of the individual analysis are given below.

Two icing conditions were calculated for each data point in the collection efficiency matrix (i.e. 2 drop sizes $\times 2$ mass flows $\times 2$ angles-of-attack) for the Boeing 737-300 inlet. The icing conditions were chosen to loosely match a rime and a mixed hold condition. For the rime condition an icing time of 30 minutes, an LWC of $.2 \mathrm{~g} / \mathrm{m}^{3}$ and a temperature of $243.1 \mathrm{~K}$ were used. For the mixed condition an icing time of 30 minutes, an LWC of $.695 \mathrm{~g} / \mathrm{m}^{3}$ and a temperature of $263.7 \mathrm{~K}$ were used.

The grid based LEWICE3D computer program parameters were chosen from experience, correlations and a desire to limit the computational resources required. A 7 bin experimentally measured droplet distribution (ref. 8) was used for the calculations (table I). The icing calculations were made using a single ice accretion time step. A LEWICE roughness parameter (ref. 3) of $.5 \mathrm{~mm}$ was used for all of the cases.

The results for the 737-300 inlet are shown in figures 7-18.The ice shape and parameter plots were made along radial cuts parallel to the flow direction.

The surface mach number and heat transfer distributions are presented in figures 7,8 . In general, the agreement between the experimental and computed surface mach number is excellent. Although no experimental data was available for the heat transfer distributions, the analytical results appear reasonable in that they follow trends set by the surface mach number distributions (i.e where there are high mach numbers there are high heat transfer coefficients).

Figures 9-12 depict the overall picture of the collection efficiency for the inlet. The calculations were generated by using a large matrix of particles $(200 \times 400)$. The calculations although expensive ( $\sim 6$ hours) give a much broader picture of the collection efficiency characteristics of the inlet.

The effect of drop size on collection efficiency can be seen in figure 9. Increasing the drop size results in a higher collection efficiency on the lip and centerbody of the inlet. Increasing the 
drop size also results in a less uniform collection efficiency distribution at the compressor face with larger peak values and larger shadow zones (i.e. areas where no droplets impact). This is because the more massive drops could not follow the flow around the inlet lip.

The effect of droplet distribution can be seen in figure 10. The droplet distribution case yields smaller peak collection efficiencies on the inlet lip with a larger extent of impingement. The collection efficiencies on the centerbody are larger for the distribution case. For the compressor face the monodisperse case generates larger collection efficiencies with a greater degree of uniformity.

Figure 11 illustrates the effect of mass flow on the collection efficiency of the inlet. The effect of increasing mass flow is to increases the amount of shadowing and nonuniformity on the compressor face. Increasing the mass flow moves the maximum collection efficiency on the inlet lip more towards the outside of the inlet.

Figure 12 illustrates the effect of increasing angle-of-attack on the collection efficiency of the inlet. Increasing the angle-of-attack results in the peak collection efficiency moving more towards the inside of the upper lip and more towards outside on the lower lip. The collection efficiency for the right and left lips appear unaffected by changes in angle-of-attack. Increasing the angle-of-attack results in a higher nonuniformity with higher peaks on the compressor face.

Figures 13-16 illustrate the collection efficiency comparisons between experiment and calculation. The largest problem in validating trajectory codes using experimental impingement data is defining favorable agreement. The evaluation process is at best subjective for two reasons. First, it is difficult to generate an exact experimental curve because the impingement data is statistical in nature and because only a small number of samples are taken (3-5) for each test condition. Secondly, the insensitivity of the method to small amounts of dye makes the exact determination of impingement limits difficult. In judging the quality of the comparisons the following criteria are used:

a) agreement in the general shape of curves

b) the analytical curve position within the experimental repeatability band

c) agreement in the location and size of the maximum collection efficiency

d) agreement of the impingement limits

For any given comparison one or more of these criteria may be satisfied. The impingement limits may not match well but the maximum collection efficiency is close. The shape of the curve is close but the maximum collection efficiency might not match. The experimental repeatability must be taken into count when making these judgements. Figure 13 shows a typical collection efficiency comparison between prediction and experiment for a NACA 65-015 wing. If we were to compare the calculation to any of the repeats or to the average of the repeats in figure 13 we would find the comparisons reasonable but not excellent. But if the experimental repeatability is taken into account the comparisons look good except for the impingement limits. This is a typical result (ref. 8,18 ). This could be due to insufficiencies in the flow code, the trajectory codes or in the experimental technique. 
Figure 14 depicts the range of quality of the comparisons. Figure $14 \mathrm{a}$ represents about the best comparison for the inlet while figure $14 \mathrm{~b}$ represents about the worst comparison. For both curves the general shape of the predicted curve is correct. For figure 14a the comparison is good everywhere except for the maximum collection efficiency. The code slightly underpredicts the maximum collection efficiency. For figure $14 \mathrm{~b}$ the agreement is good for the upper surface and for the maximum collection efficiency. The agreement deteriorates on the underside of the wing where the code overpredicts the collection efficiency and the lower impingement limit. If the experimental repeatability were taken into account the comparison would improve slightly.

Figure 15,16 show the overall comparison of experiment and calculation. On average, the agreement is good. The experimental and computational results agree well in shape of curve, area under the curve, maximum collection efficiency and impingements limit for the most part.

The computed ice shapes are presented in figures 17-20. Although no experimental data was available the results looked consistent with the conditions for which the shapes were generated, and with the collection efficiency distribution and with the heat transfer distribution. At a given positive inlet angle-of-attack the ice shape transitions from more towards the outside of the inlet to more towards the inside of the inlet as we traverse from the lower lip around the inlet to the upper lip. For a given inlet angle-of-attack increasing the mass flow results in an ice shape that is more towards the outside of the inlet.

\section{CONCLUSION}

The grid based LEWICE3D-VSAERO-ICEGRID3D combination proved to be an inexpensive, flexible, accurate ice protection system design tool. The flow and ice accretion calculations were done quickly, cheaply and accurately for a range of 3D conditions.

The ICEGRID3D, VSAERO, grid based LEWICE3D, combination was, in general, inexpensive to operate. The grid calculation took approximately 5 hours and the VSAERO flow calculations took on the average of 1.4 hours for the isolated inlet case on the SGI Power Challenge computer. The ice accretion calculations required about .27 hours per section-of-interest using a seven bin distribution. These run times imply calculation times of several hours for a full aircraft configuration on a large workstation or overnight on a modern PC.

In general, the calculations for surface velocity, heat transfer, collection efficiency and ice shape compared well with experiment where data was available and with intuition where no data was available. The surface velocities for the inlets agreed well with experiment. Although no heat transfer data was available for the inlets the results followed velocity gradient trends and appeared reasonable. The calculated collection efficiency compared favorably for all cases considering the inviscid flow approximation used and the repeatability and accuracy of the collection efficiency data. The ice shape predictions appeared reasonable and representative of the conditions from which they were derived. The rime and mixed shapes followed trends set by the collection efficiency and heat transfer coefficient, respectively. 


\section{REFERENCES}

1. Bowden, D.T., Gensemer, A.E.,and Skeen, C.A., "Engineering Summary of Airframe Icing Technical Data," FAA ADS-4, December 1963.

2. Lozowski, E.P., and Oleskiw, M.M., "Computer Modeling of Time-Dependent Rime Icing in the Atmosphere," CRREL 83-2, Jan. 1983

3. Ruff, G.A., Berkowitz, B.M., "Users manual for the NASA Lewis Ice Accretion Prediction code (LEWICE),” NASA CR 185129, May 1990.

4. Cebeci, T., Chen, H.H., and Alemdaroglu, N., "Fortified LEWICE with Viscous Effects." AIAA Paper 90-0754, Jan. 1990

5. Cansdale, J.T., and Gent, R.W., "Ice Accretion on Aerofoils in Two-Dimensional Compressible Flow - A Theoretical Model,” RAE TR 82128, January 1983.

6. Bidwell, C.S., and Potapczuk, M.G., "Users Manual for the NASA Lewis Three-Dimensional Ice Accretion Code (LEWICE3D)," NASA TM 105974, December 1993.

7. Maskew, B., "Program VSAERO Theory Document: A Computer Program for Calculating Nonlinear Aerodynamic Characteristics of Arbitrary Configurations, "NASA CR 4023, September 1987.

8. Papadakis, M., Elangonan, G.A., Fruend, G.A.,Jr., Breer, M., and Whitmer, L., “An experimental Method for Measuring Water Droplet Impingement Efficiency on Two-and ThreeDimensional Bodies," NASA CR 4257, DOT/FAA/CT-87/22, November 1989.

9. Soedher, R.H., Andracchio, C.R., "NASA Lewis Icing Research Center Tunnel User Manual," NASA TM 82790, 1990.

10. Potapczuk, M.G. and Bidwell, C.S., "Swept Wing Ice Accretion Modeling," NASA TM 103114, January. 1990.

11. Potapczuk, M.G. and Bidwell, C.S., "Numerical Simulation of Ice Growth on a MS-317 Swept Wing Geometry," NASA TM 103705, January 1991.

12. Reehorst, A. L., "Prediction of Ice Accretion on a Swept NACA 0012 Airfoil and Comparisons to Flight Test Results," NASA TM 105368, January 1992.

13. Mohler, S.R., Bidwell, C.S., "Comparison of Two-Dimensional and Three-Dimensional Droplet Trajectory Calculations in the Vicinity of Finite Wings," NASA TM 105617, January 1992. 
14. Bidwell, C.S., "Ice Accretion Prediction for a Typical Commercial Transport Aircraft," NASA TM 105976, January 1993.

15. Johnson, F.T., Samant, S.S., Bieterman, M.B., Melvin, R.G., Young, D.P., Bussoletti, J.E., and Hilmes, C.L., "TranAir: A Full-Potential, Solution-Adaptive, Rectangular Grid Code for Prediciting Subsonic, Transonic, and Supersonic Flows About Arbitrary Configurations," NASA CR 4348, December 1992.

16. Norment, H.G., "Calculation of Water Drop Trajectories To and About Three-Dimensional Lifting and Non-lifting Bodies In Potential Airflow,” NASA CR 3935, Oct. 1985.

17. Krogh, F.T. "Variable Order Integrators for Numerical Solutions of Ordinary Differential Equations," Jet Propulsion Lab Technology Utilization Document No. CP-32308, Nov. 1970

18. Bidwell, C.S., and Mohler, S.R., Jr., "Collection Efficiency and Ice Accretion Calculations for a Sphere, a Swept MS(1)-317 Wing, a Swept NACA-0012 Wing Tip, an Axisymmetric Inlet, and a Boeing 737-300 Inlet," NASA TM 106831, January 1995. 
TABLE I - DISCRETIZED DROPLET DISTRIBUTIONS USED IN CALCULATIONS.

\begin{tabular}{|c|c|c|}
\hline \multirow{2}{*}{$\%$ LWC } & \multicolumn{2}{|c|}{$\mathrm{d}(\mathrm{I}) / \mathrm{MVD}$} \\
\cline { 2 - 3 } & MVD, $16.4 \mu \mathrm{m}$ & MVD, $20.4 \mu \mathrm{m}$ \\
\hline \hline 5 & .3161 & .2770 \\
\hline 10 & .4981 & .4460 \\
\hline 20 & .6872 & .6617 \\
\hline 30 & 1.000 & 1.0000 \\
\hline 20 & 1.3737 & 1.5865 \\
\hline 10 & 1.9614 & 2.2943 \\
\hline 5 & 2.8288 & 3.2542 \\
\hline
\end{tabular}




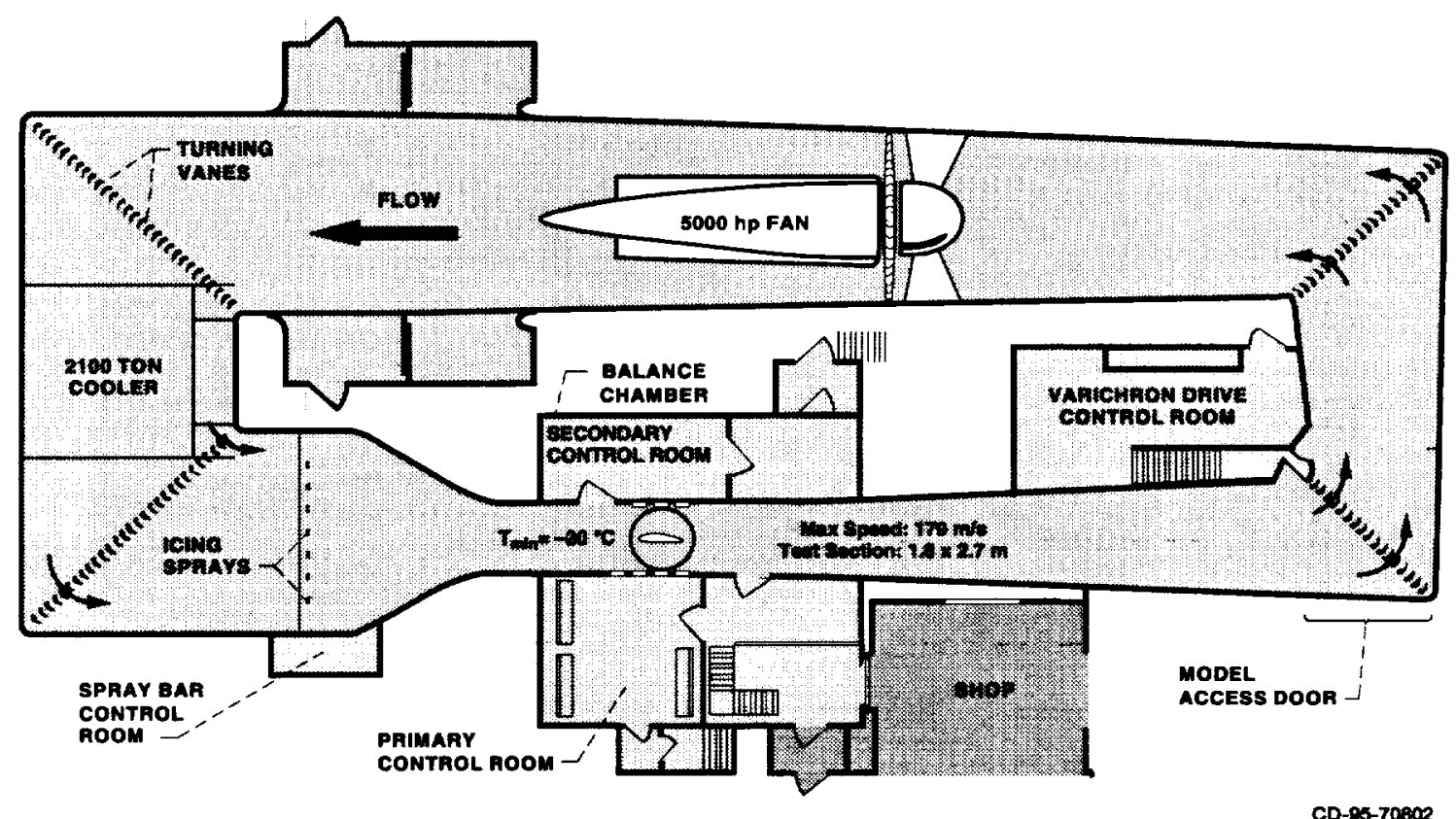

Figure 1. - NASA Lewis Icing Research Tunnel. Plan view.

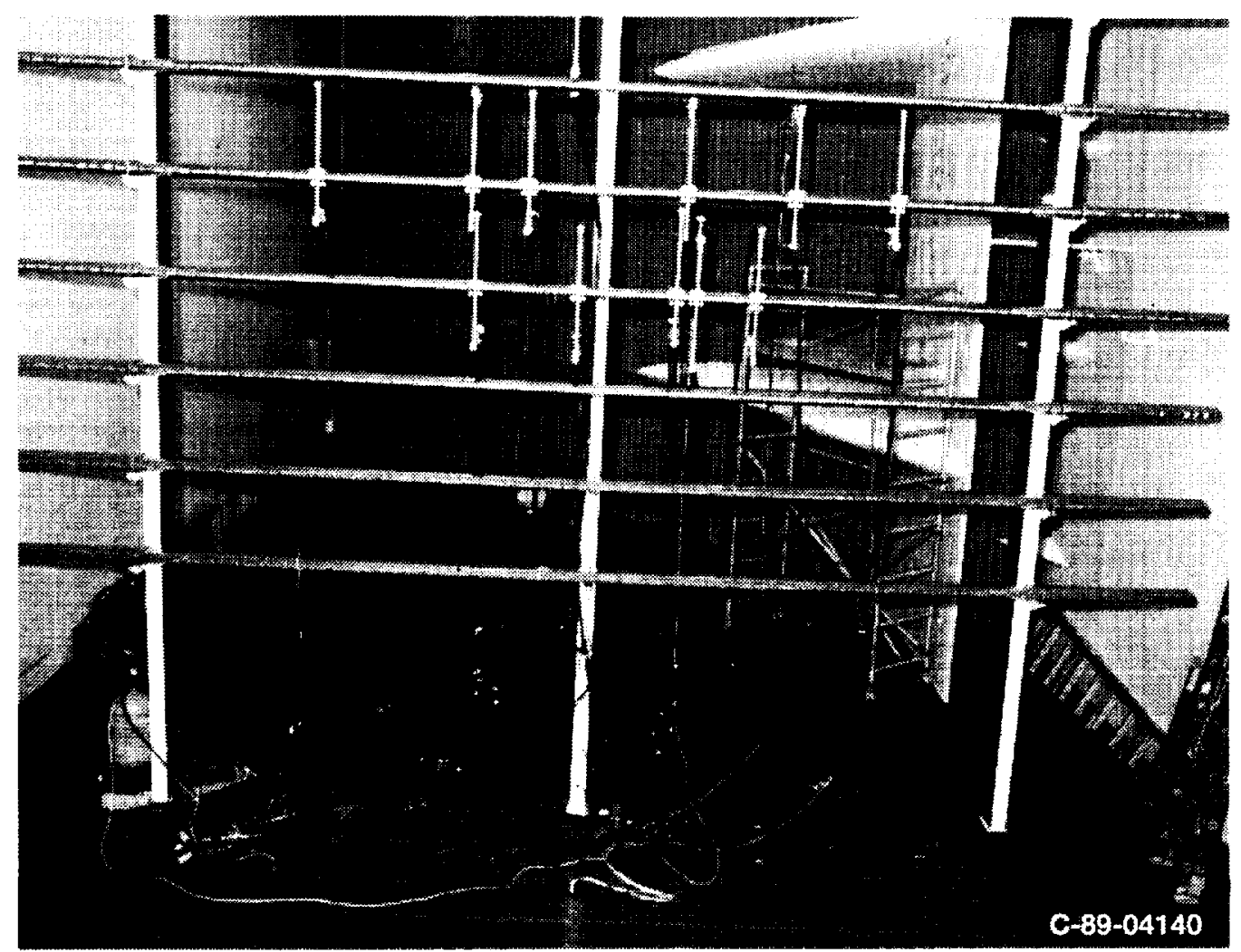

Figure 2. - Installation of spray system used for Icing Research Tunnel impingement tests. 


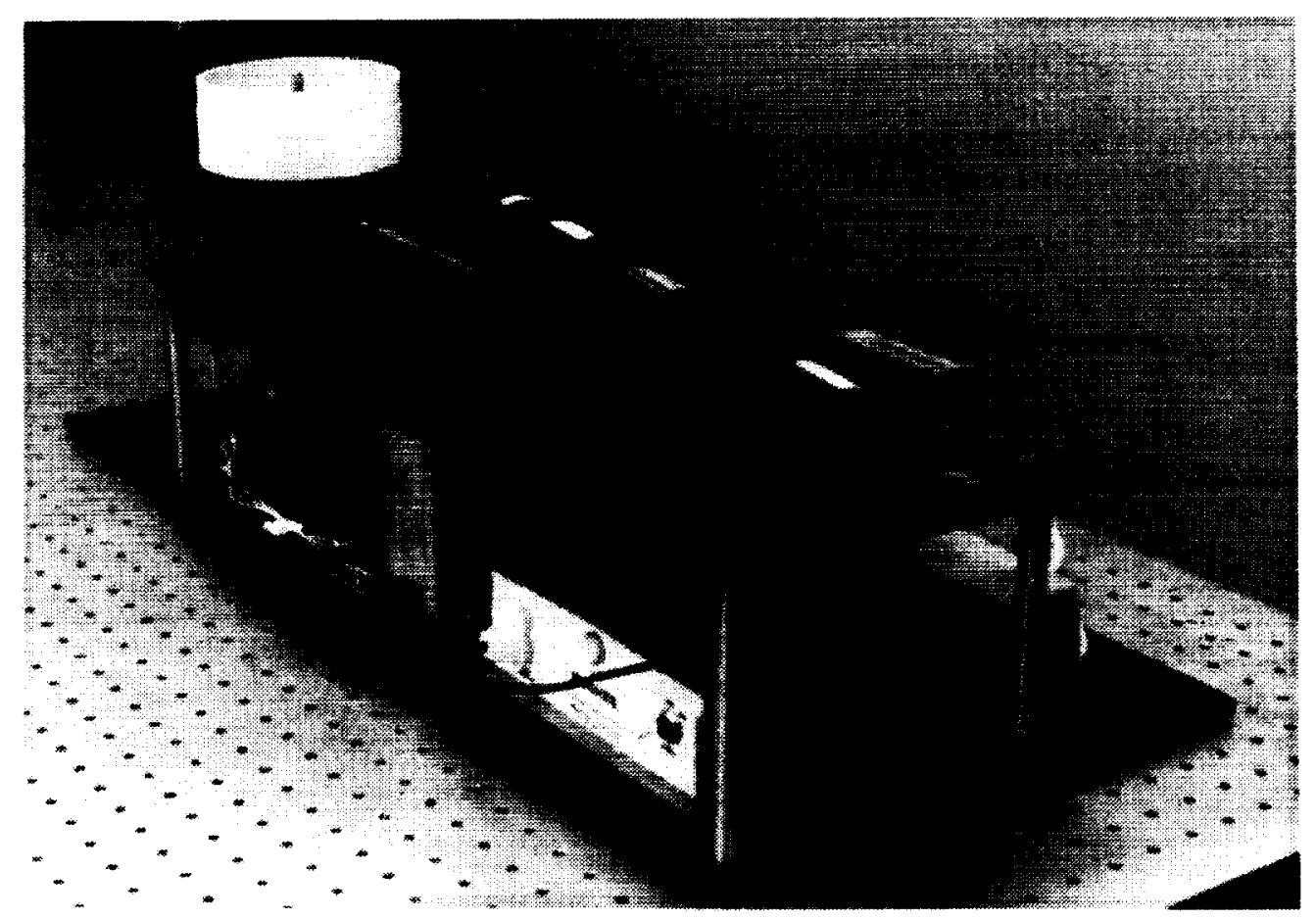

Figure 3. - Automated reflectometer used to reduce impingement data.

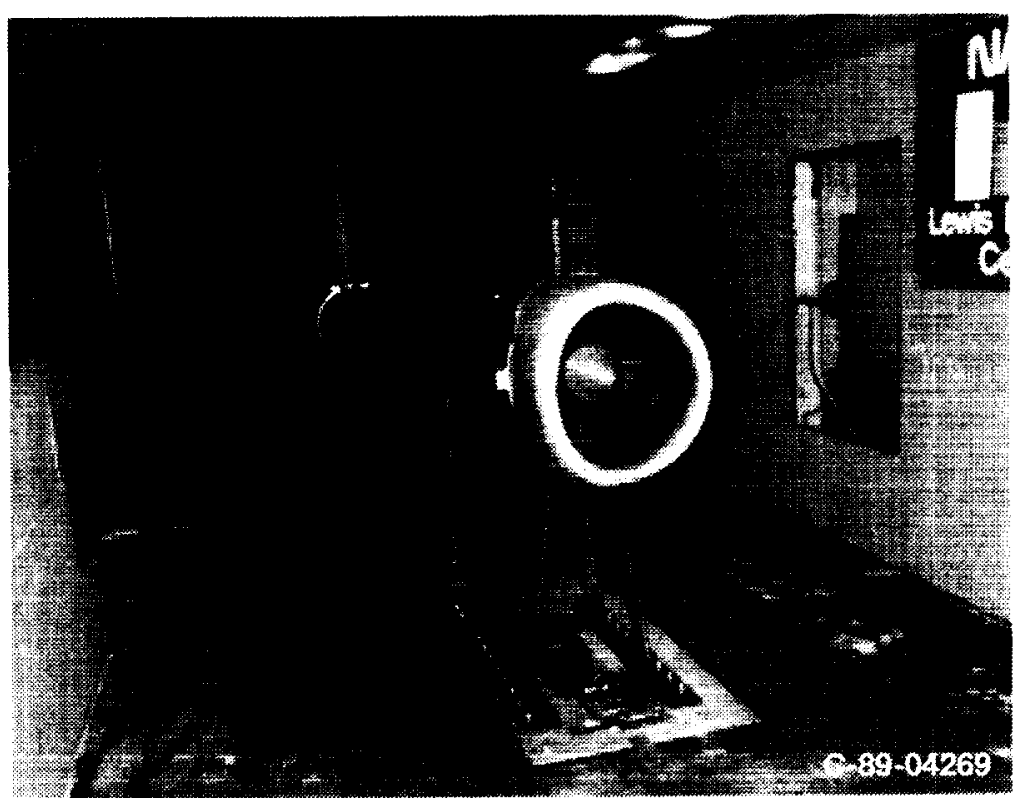

(a) Installation in IRT.

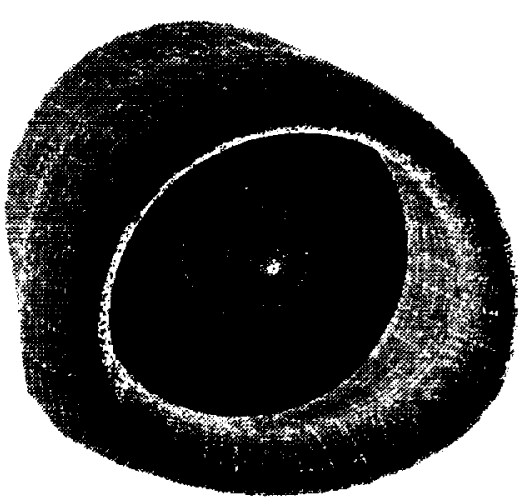

(b) VSAERO panel model.

Figure 4. - Boeing 737-300 inlet. 


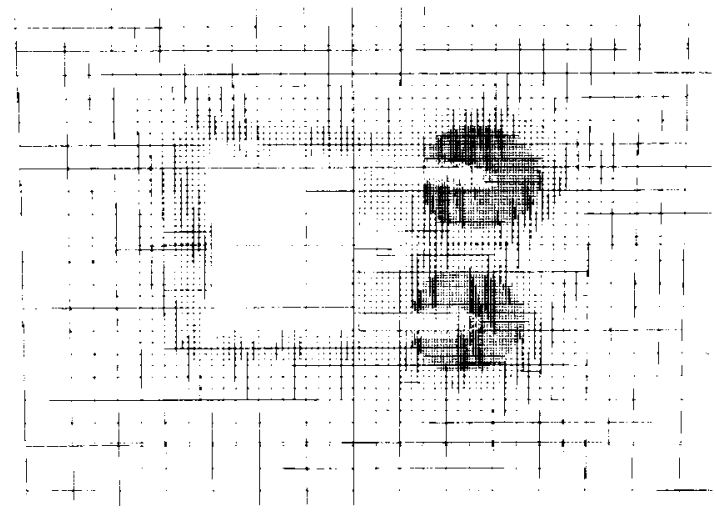

(a) $\mathrm{Y}=0$ plane.

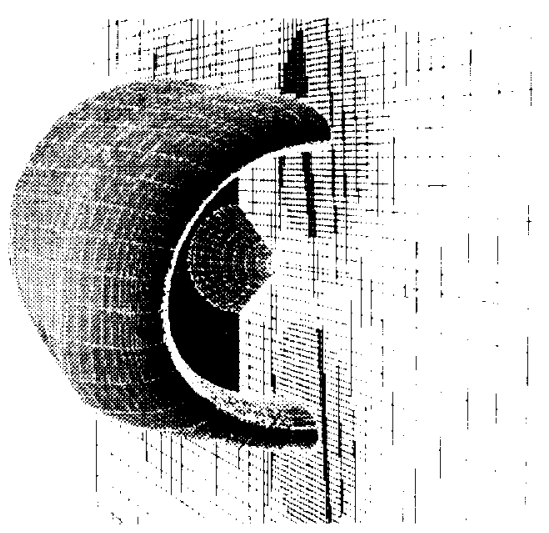

(b) VSAERO panel model and grid.

Figure 5. - Boeing 737-300 inlet ICEGRID3D grid model.

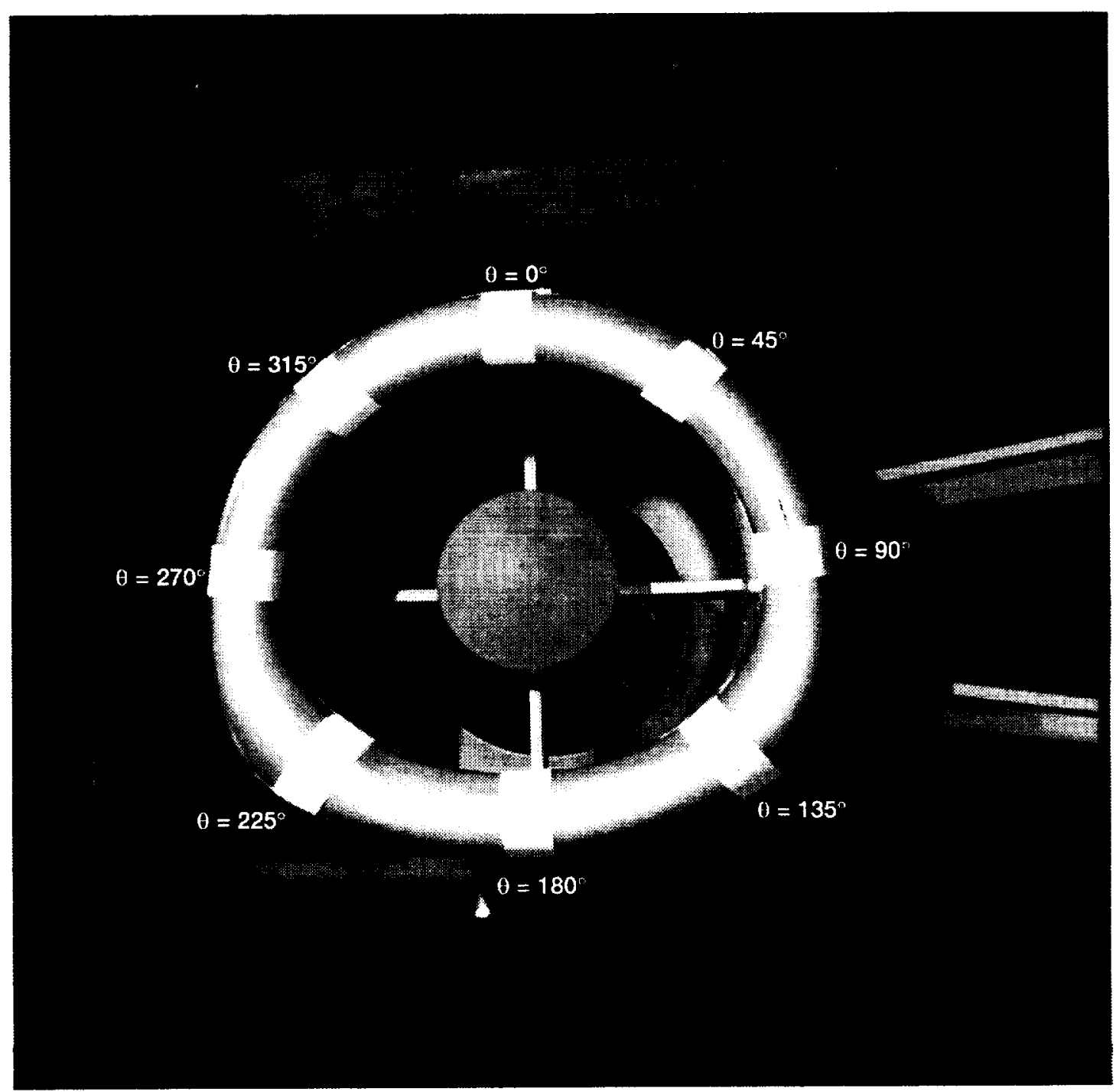

Figure 6. - Illustration of inlet blotter strip orientation. 


$$
\theta=0^{\circ} \quad \theta=45^{\circ} \quad \theta=90^{\circ} \quad \theta=135^{\circ} \quad \theta=180^{\circ}
$$
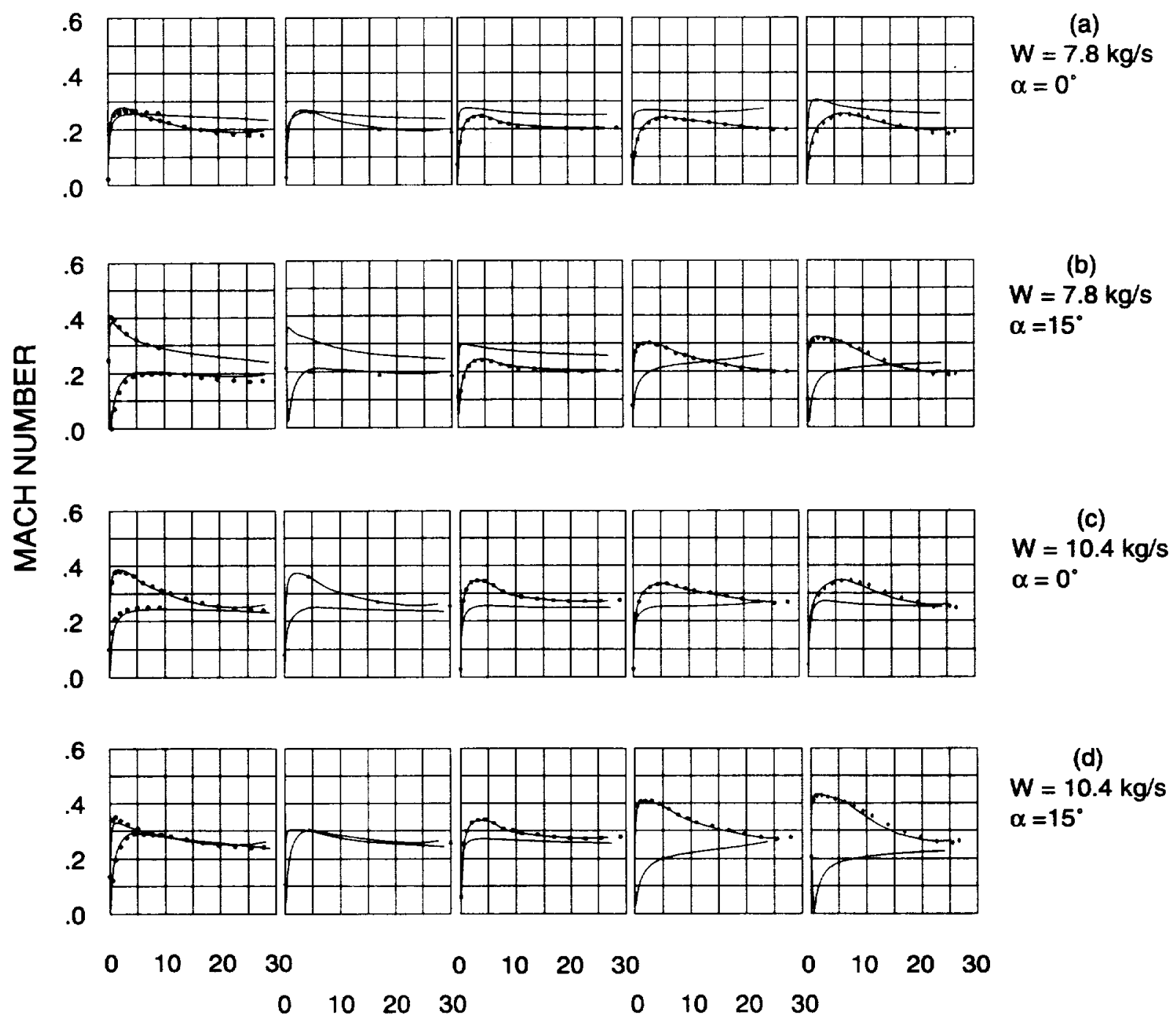

AXIAL DISTANCE (CM)

Figure 7. - Experimental and analytical surface Mach numbers for the Boeing 737-300 inlet for airspeed, $75 \mathrm{~m} / \mathrm{s}$; static temperature, $7^{\circ} \mathrm{C}$; static pressure, $95840 \mathrm{~Pa}$. 


$$
\theta=0^{\circ} \quad \theta=45^{\circ} \quad \theta=90^{\circ} \quad \theta=135^{\circ} \quad \theta=180^{\circ}
$$
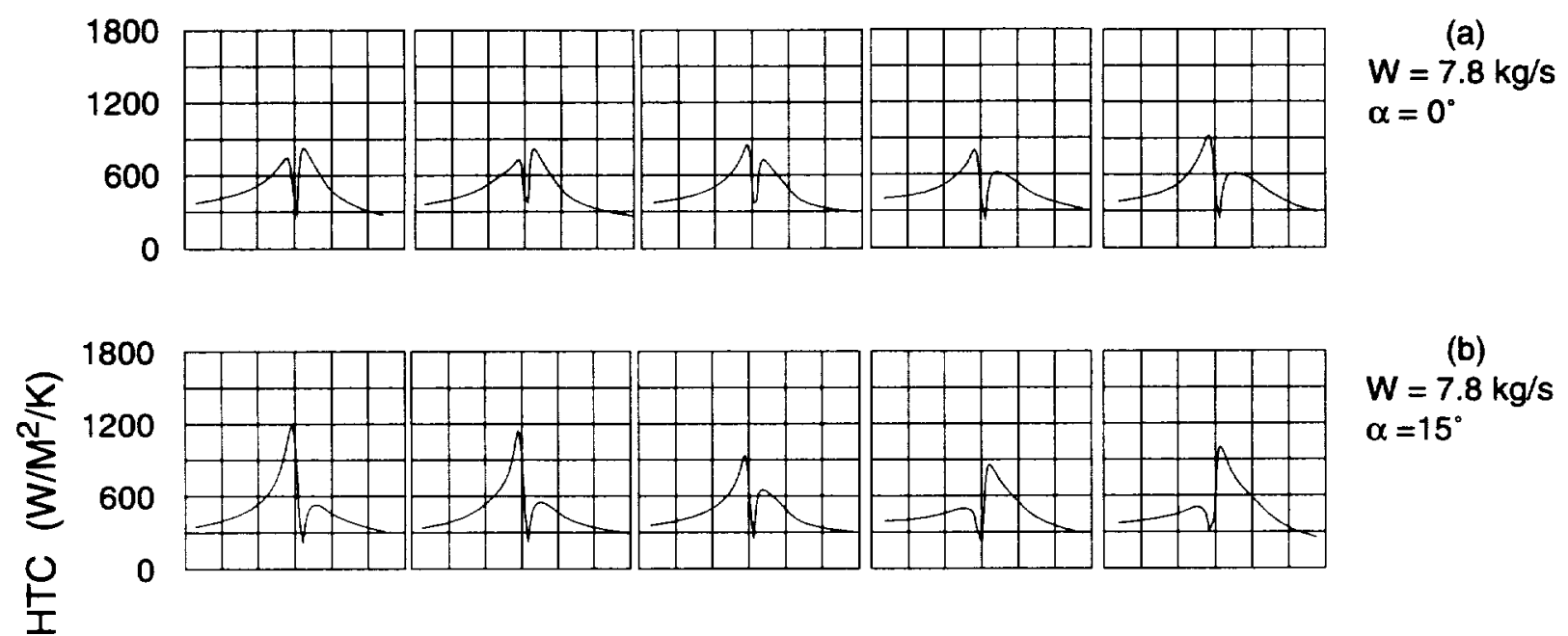

\section{(b)}

$\mathrm{W}=7.8 \mathrm{~kg} / \mathrm{s}$

$\alpha=15^{\circ}$

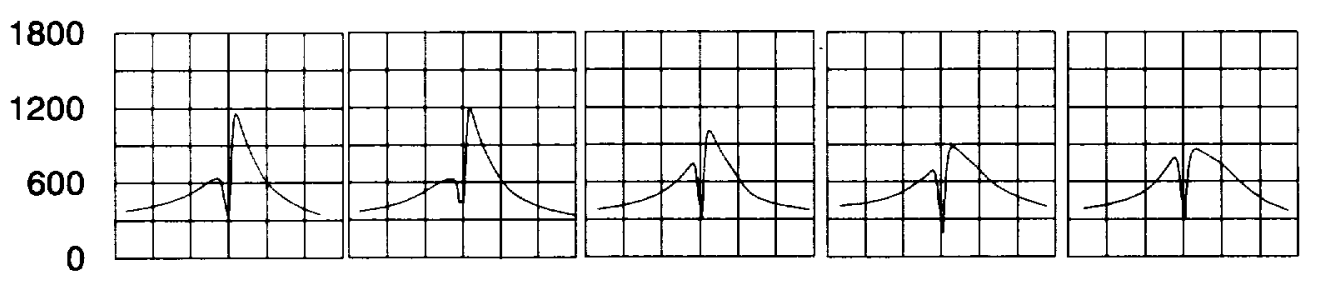

(c)

$W=10.4 \mathrm{~kg} / \mathrm{s}$

$\alpha=0^{\circ}$

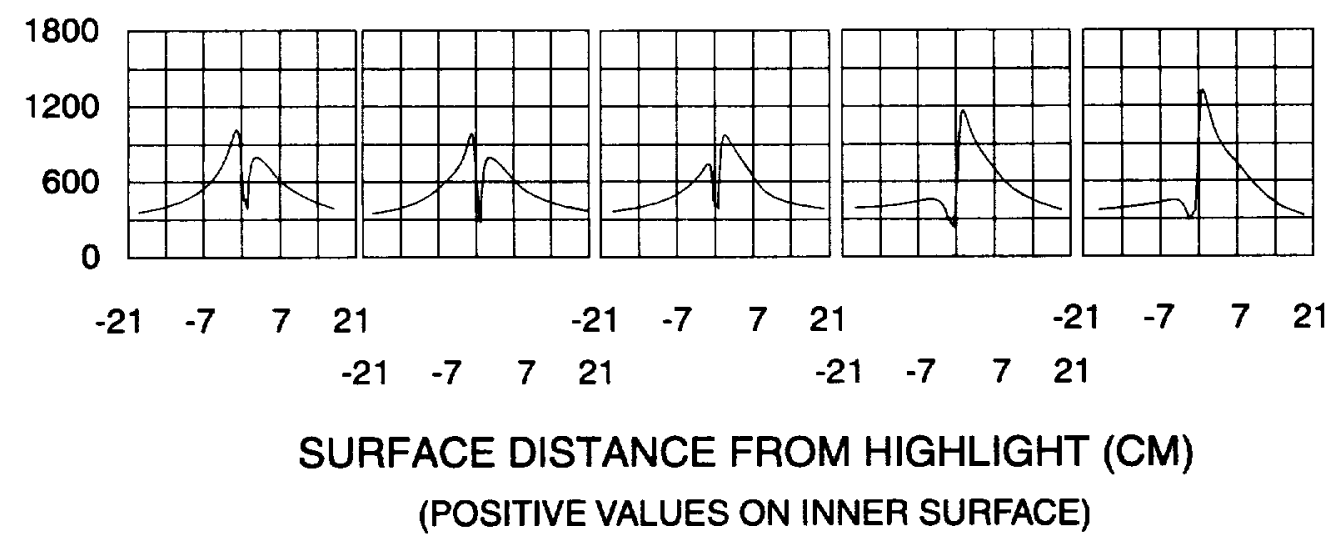

Figure 8. - Analytical heat transfer distribution for the Boeing 737-300 inlet for airspeed, $75 \mathrm{~m} / \mathrm{s}$; static temperature, $7^{\circ} \mathrm{C}$; static pressure, $95840 \mathrm{~Pa}$. 

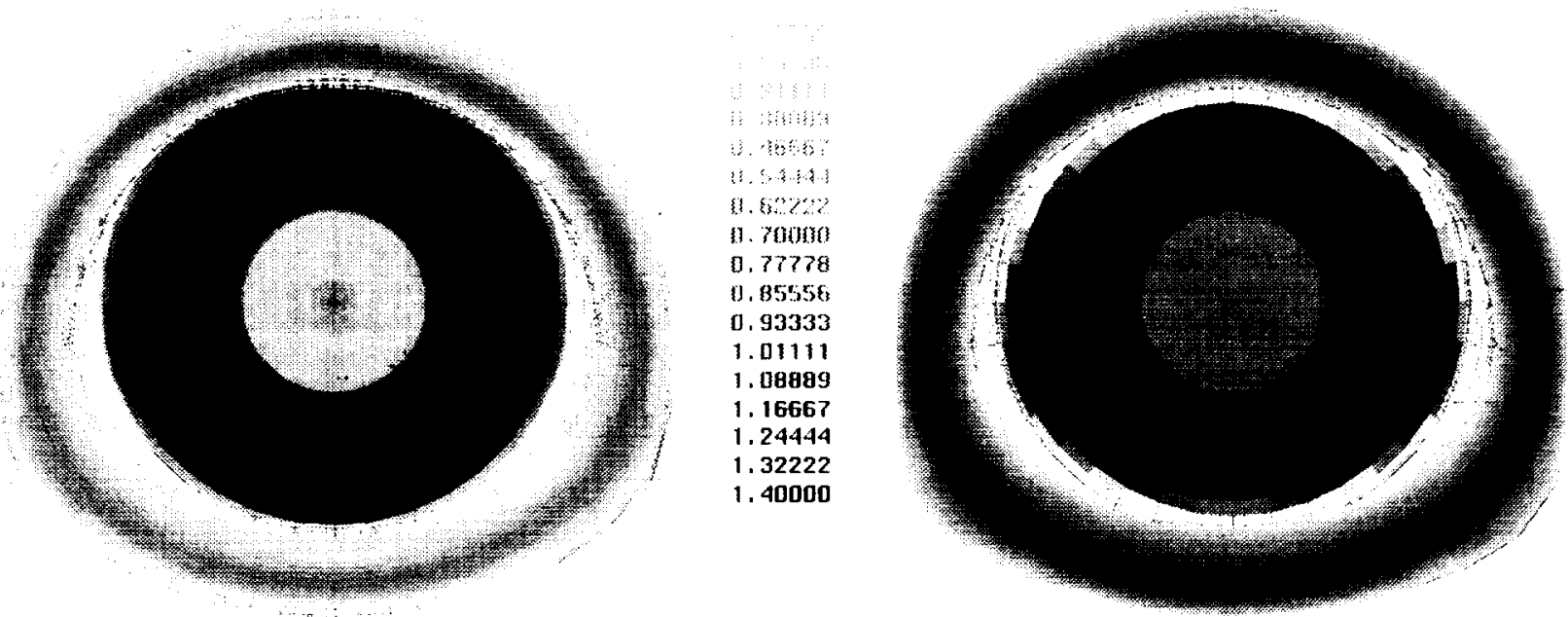

(a) Monodisperse droplet diameter, $9.08 \mu \mathrm{m}$.

(b) Monodisperse droplet diameter, $66.26 \mu \mathrm{m}$.

Figure 9. - Analytical collection efficiency for the Boeing 737-300 inlet for angle-of-attack, $0^{\circ}$; airspeed, $75 \mathrm{~m} / \mathrm{s}$; static temperature, $7^{\circ} \mathrm{C}$; static pressure, $95840 \mathrm{~Pa}$; mass flow, $7.8 \mathrm{~kg} / \mathrm{s}$.

\section{BETA CONTOURS}
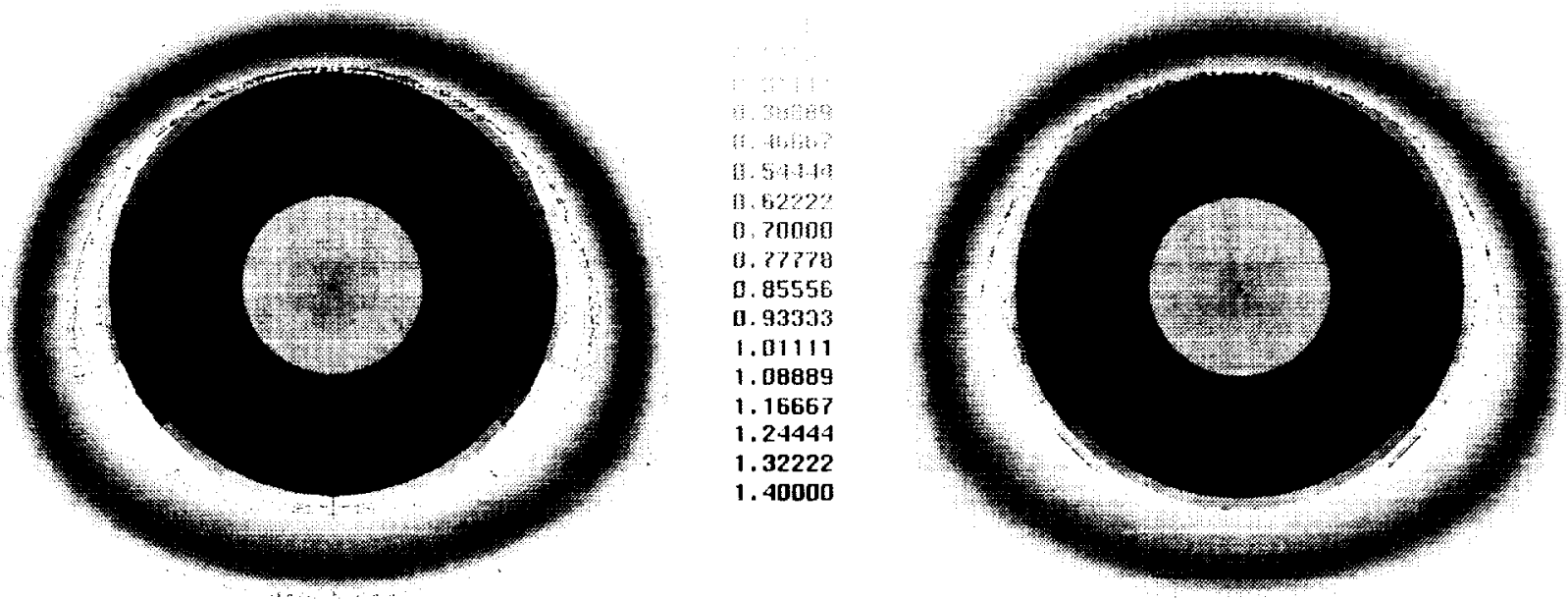

(a) Monodisperse droplet diameter, $20.36 \mu \mathrm{m}$.

(b) Droplet distribution MVD, $20.36 \mu \mathrm{m}$.

Figure 10. - Analytical collection efficiency for the Boeing 737-300 inlet for angle-of-attack, $0^{\circ}$; airspeed, $75 \mathrm{~m} / \mathrm{s}$; static temperature, $7^{\circ} \mathrm{C}$; static pressure, $95840 \mathrm{~Pa}$; mass flow, $7.8 \mathrm{~kg} / \mathrm{s}$. 


\section{BETA CONTOURS}

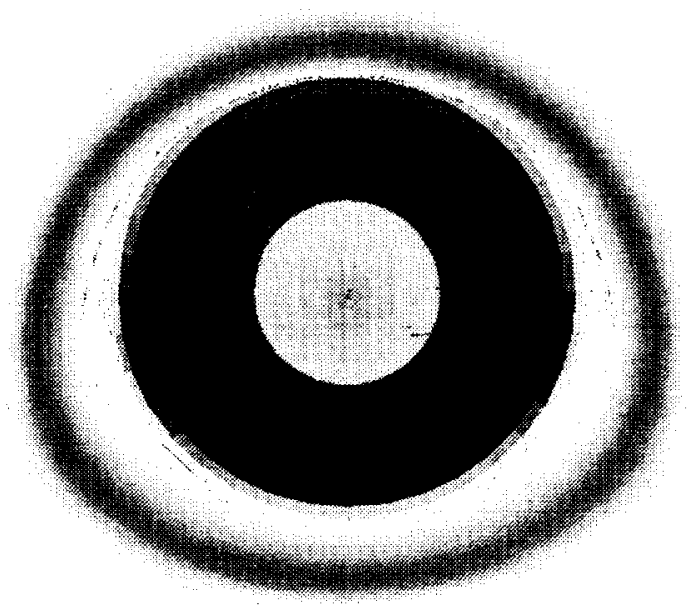

(a) Mass flow, $7.8 \mathrm{~kg} / \mathrm{s}$.

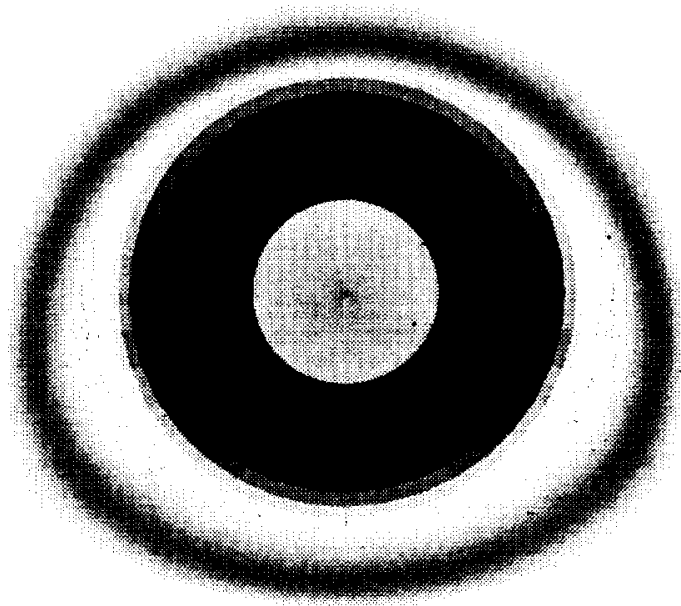

(b) Mass flow, $10.4 \mathrm{~kg} / \mathrm{s}$.

Figure 11. - Analytical collection efficiency for the Boeing 737-300 inlet for angle-of-attack, $0^{\circ}$; airspeed, $75 \mathrm{~m} / \mathrm{s}$; static temperature, $7^{\circ} \mathrm{C}$; static pressure, $95840 \mathrm{~Pa}$; MVD, $20.36 \mu \mathrm{m}$.

BETA CONTOURS

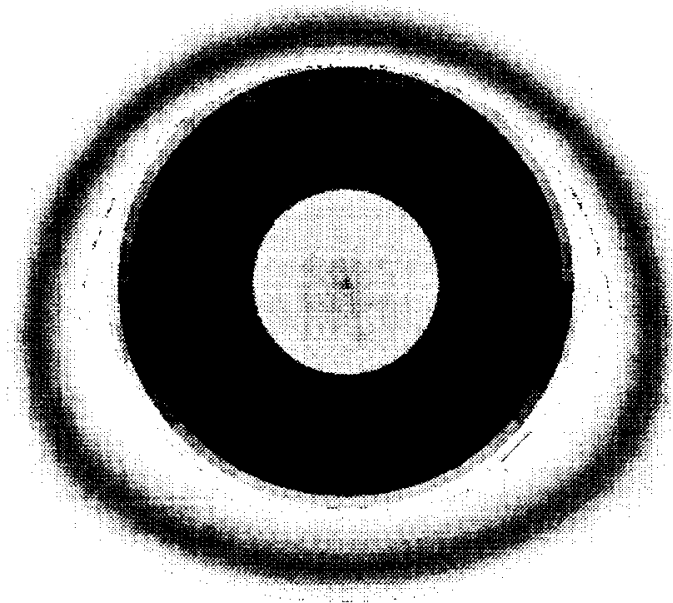

(a) Angle-of-attack, $0^{\circ}$.

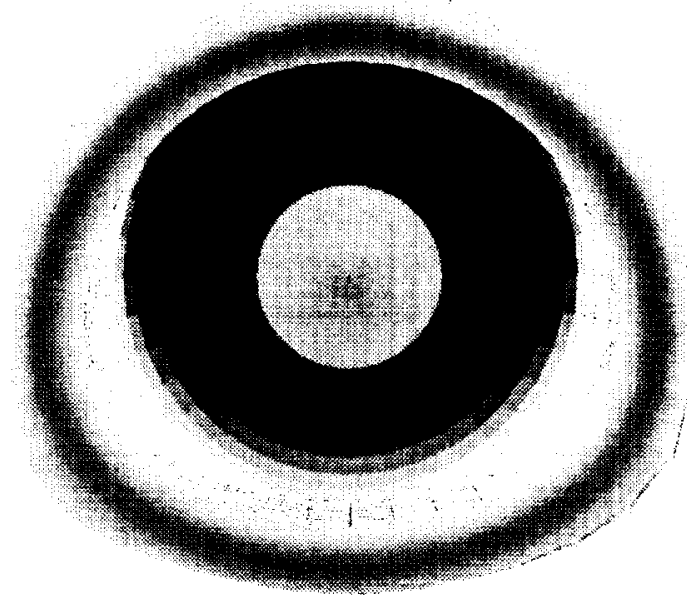

(b) Angle-of-attack, $15^{\circ}$.

Figure 12. - Analytical collection efficiency for the Boeing 737-300 inlet for airspeed, $75 \mathrm{~m} / \mathrm{s}$; static temperature, $7^{\circ} \mathrm{C}$; static pressure, $95840 \mathrm{~Pa}$; MVD, $20.36 \mu \mathrm{m}$; mass flow, $7.8 \mathrm{~kg} / \mathrm{s}$. 


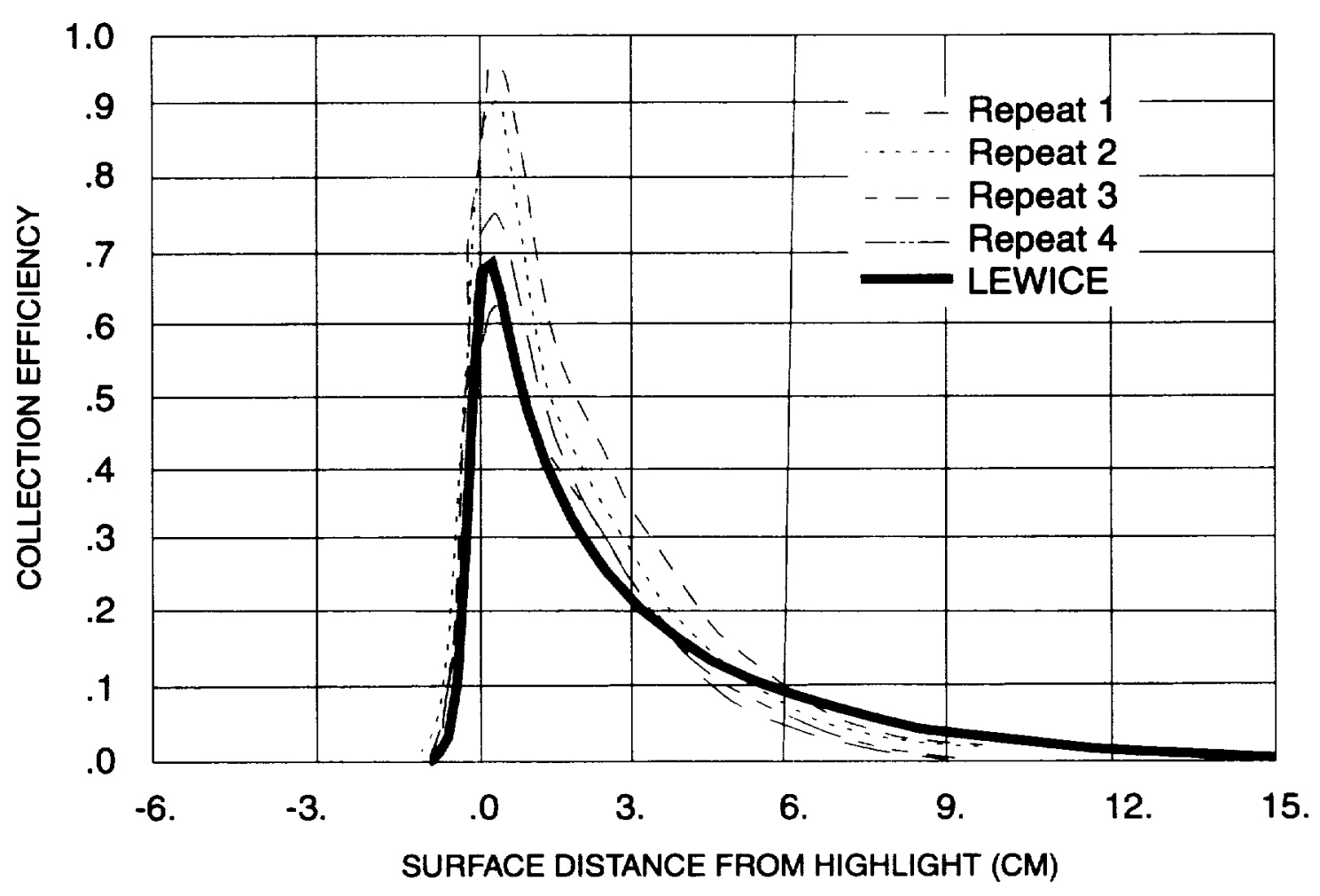

Figure 13. - Experimental and analytical collection efficiency for the NACA 65-015 wing for MVD, $16.45 \mu \mathrm{m}$; angle-of-attack, $8^{\circ}$; airspeed, $75 \mathrm{~m} / \mathrm{s}$; static temperature, $7^{\circ} \mathrm{C}$; static pressure, $95840 \mathrm{~Pa}$.

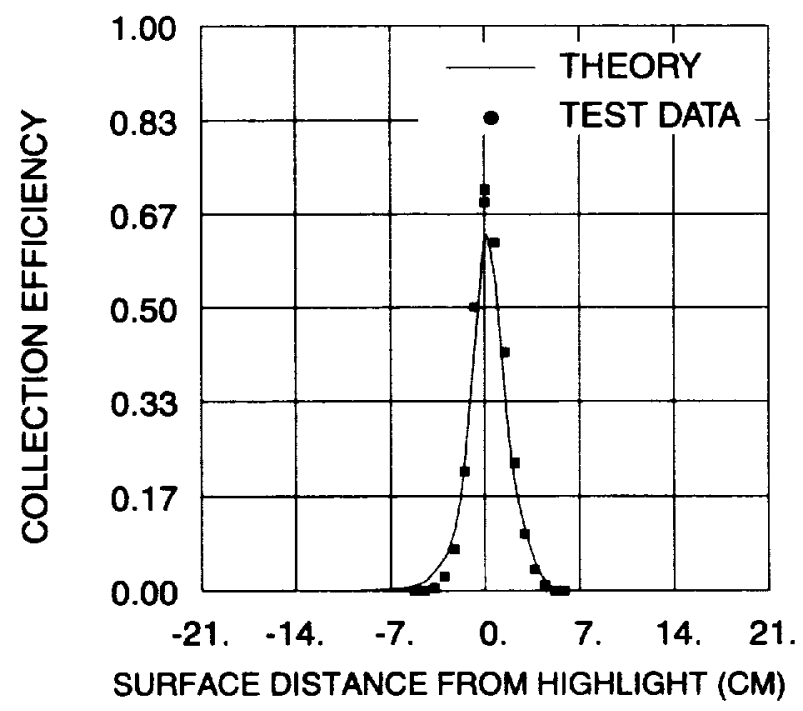

(a) Mass flow, $7.8 \mathrm{~kg} / \mathrm{s} ; \alpha, 0^{\circ} ; \theta=90^{\circ}$.

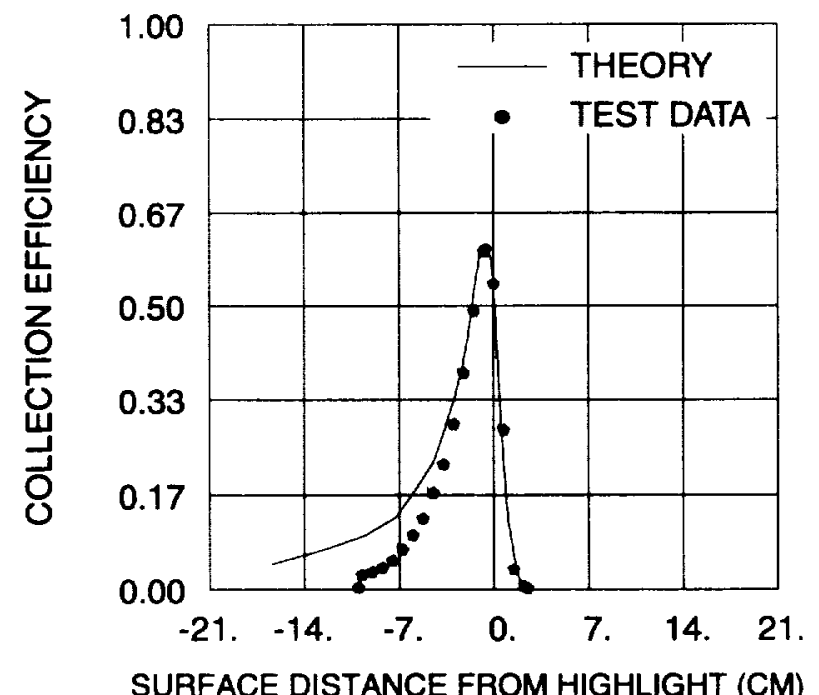

(b) Mass flow, $10.4 \mathrm{~kg} / \mathrm{s} ; \alpha, 15^{\circ} ; \theta=135^{\circ}$.

Figure 14. - Experimental and analytical collection efficiency for the Boeing 737-300 inlet for MVD, $20.36 \mu \mathrm{m}$; airspeed, $75 \mathrm{~m} / \mathrm{s}$; static temperature, $7^{\circ} \mathrm{C}$; static pressure, $95840 \mathrm{~Pa}$. 


$$
\theta=0^{\circ} \quad \theta=45^{\circ} \quad \theta=90^{\circ} \quad \theta=135^{\circ} \quad \theta=180^{\circ}
$$
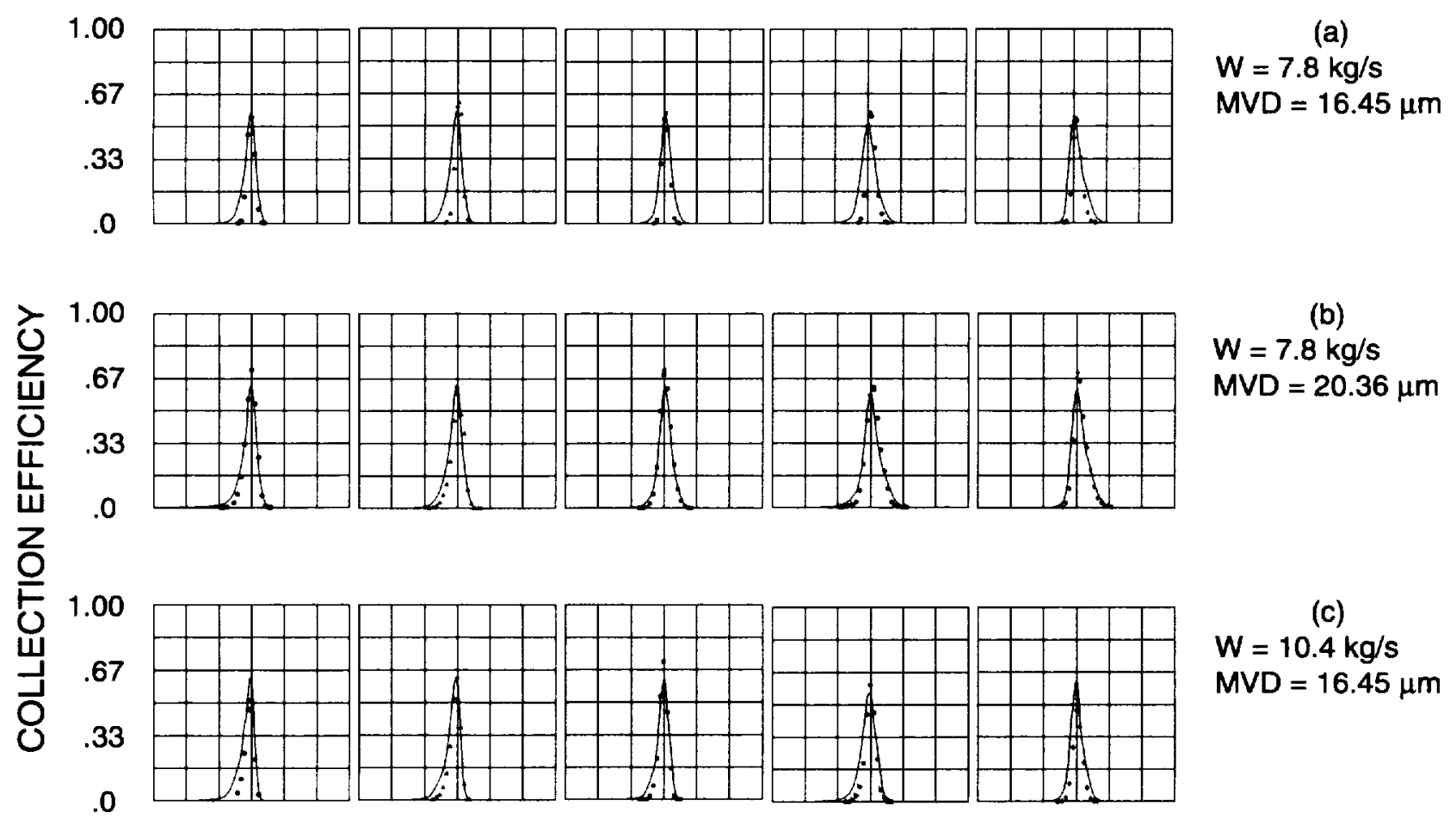

$W=7.8 \mathrm{~kg} / \mathrm{s}$

MVD $=20.36 \mu \mathrm{m}$

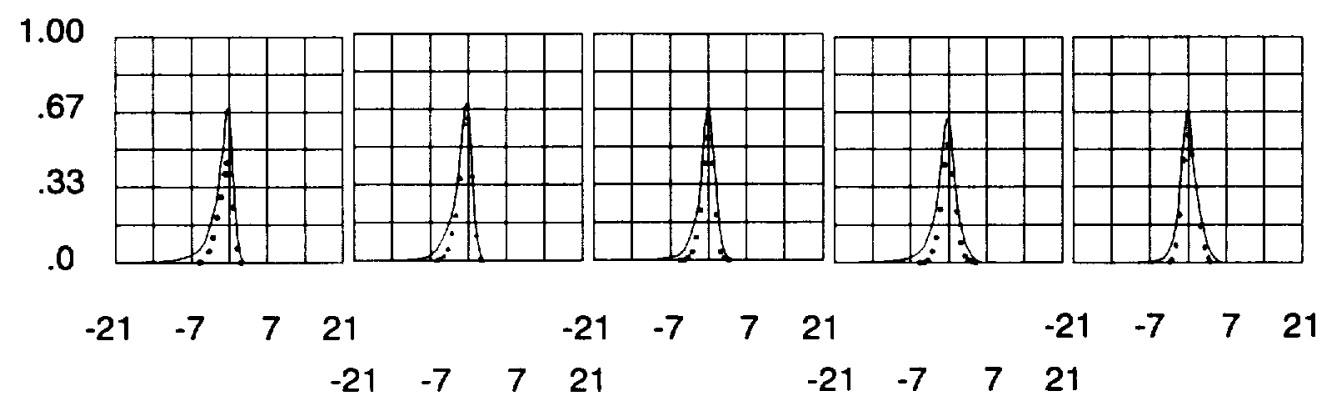

SURFACE DISTANCE FROM HIGHLIGHT (CM)

(POSITIVE VALUES ON INNER SURFACE)

THEORY

- TEST DATA

Figure 15. - Experimental and analytical collection efficiency for the Boeing 737-300 inlet for angle-of-attack, $0^{\circ}$; airspeed, $75 \mathrm{~m} / \mathrm{s}$; static temperature, $7^{\circ} \mathrm{C}$; static pressure, $95840 \mathrm{~Pa}$. 


$$
\theta=0^{\circ} \quad \theta=45^{\circ} \quad \theta=90^{\circ} \quad \theta=135^{\circ} \quad \theta=180^{\circ}
$$

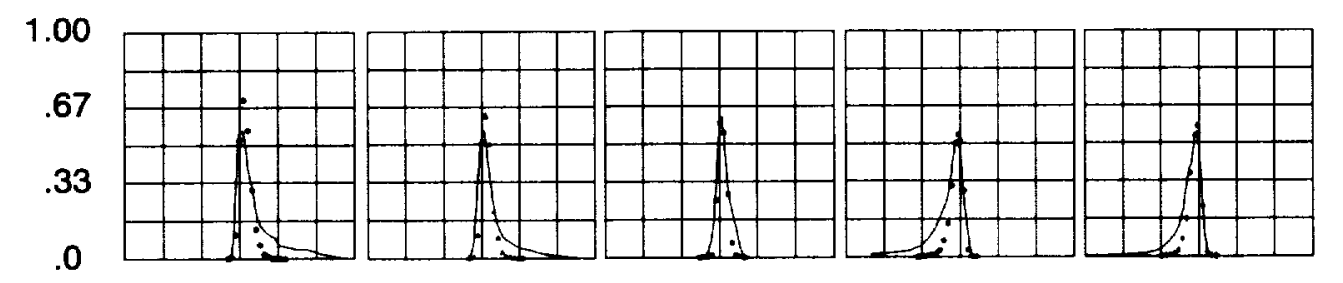

$W=7.8 \mathrm{~kg} / \mathrm{s}$

$M V D=16.45 \mu \mathrm{m}$

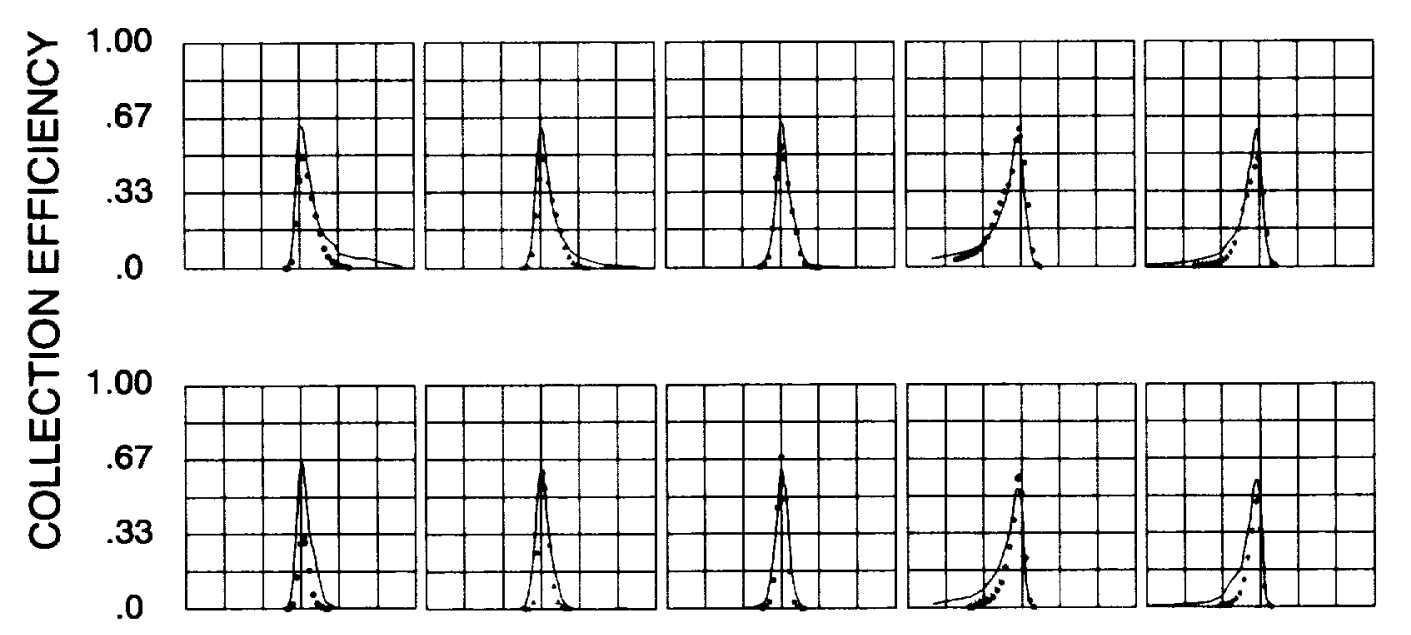

(b)

$W=7.8 \mathrm{~kg} / \mathrm{s}$

$M V D=20.36 \mu \mathrm{m}$

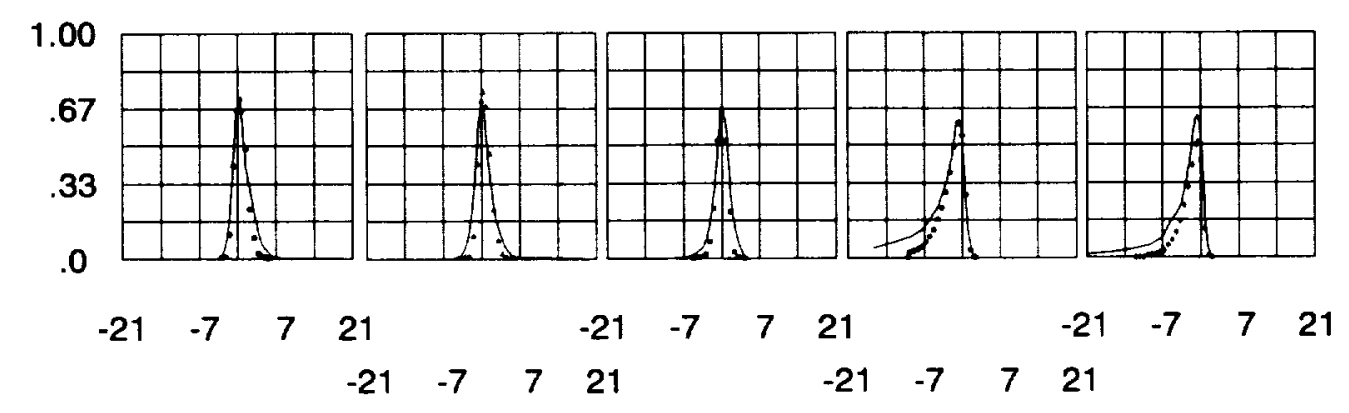

SURFACE DISTANCE FROM HIGHLIGHT (CM)

(POSITIVE VALUES ON INNER SURFACE)

\section{THEORY}

- $\quad$ TEST DATA

Figure 16. - Experimental and analytical collection efficiency for the Boeing 737-300 inlet for angle-of-attack, $15^{\circ}$; airspeed, $75 \mathrm{~m} / \mathrm{s}$; static temperature, $7^{\circ} \mathrm{C}$; static pressure, $95840 \mathrm{~Pa}$. 


$$
\theta=0^{\circ} \quad \theta=45^{\circ} \quad \theta=90^{\circ} \quad \theta=135^{\circ} \quad \theta=180^{\circ}
$$

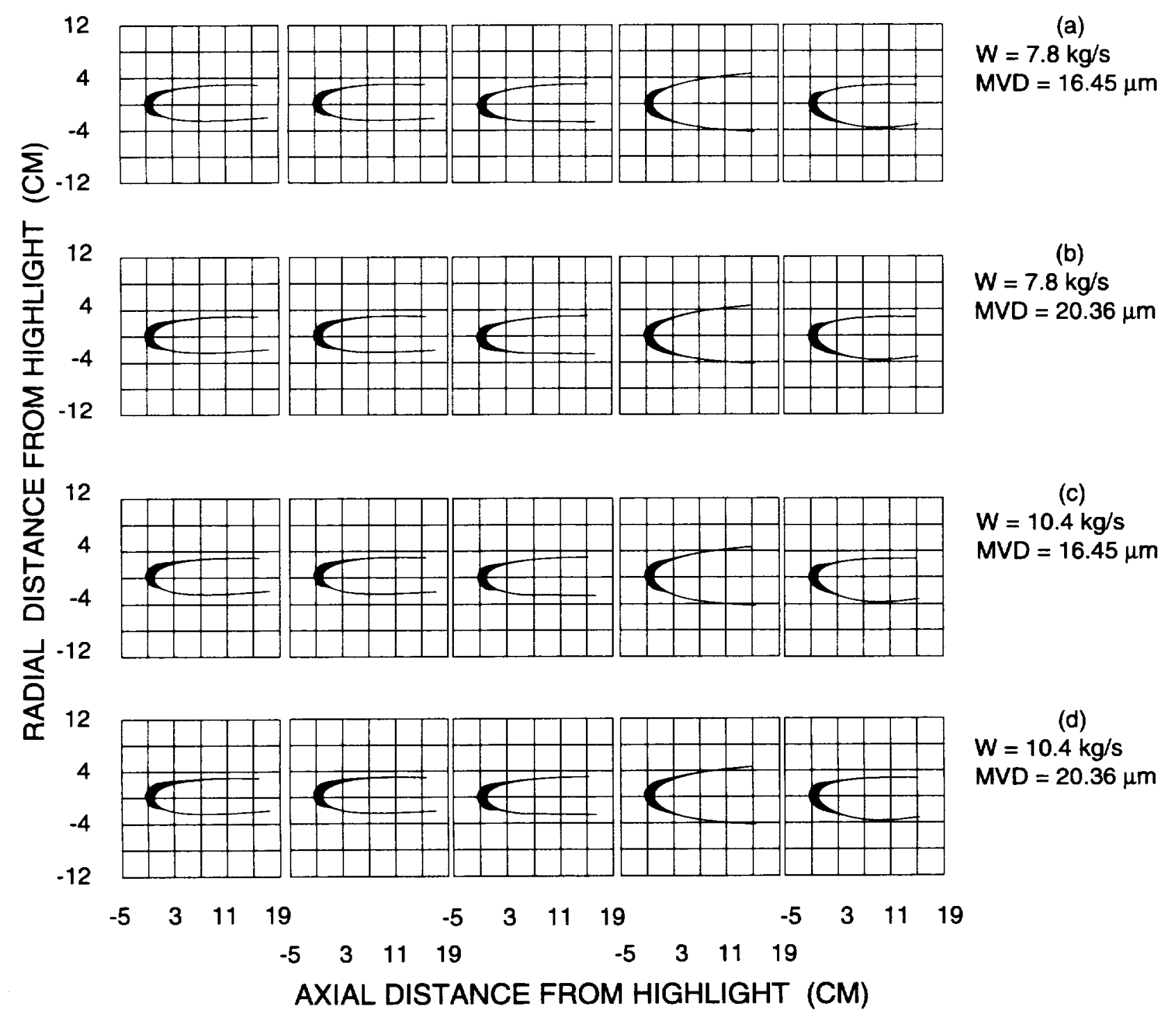

Figure 17. - Analytical ice shapes for the Boeing 737-300 inlet for $0^{\circ}$ angle-of-attack. Icing conditions: airspeed, $75 \mathrm{~m} / \mathrm{s}$; icing time, 30 minutes; static temperature, $-29.9^{\circ} \mathrm{C}$; static pressure, $95840 \mathrm{~Pa}$; liquid water content, $.2 \mathrm{~g} / \mathrm{m}^{3}$. 


$$
\theta=0^{\circ} \quad \theta=45^{\circ} \quad \theta=90^{\circ} \quad \theta=135^{\circ} \quad \theta=180^{\circ}
$$

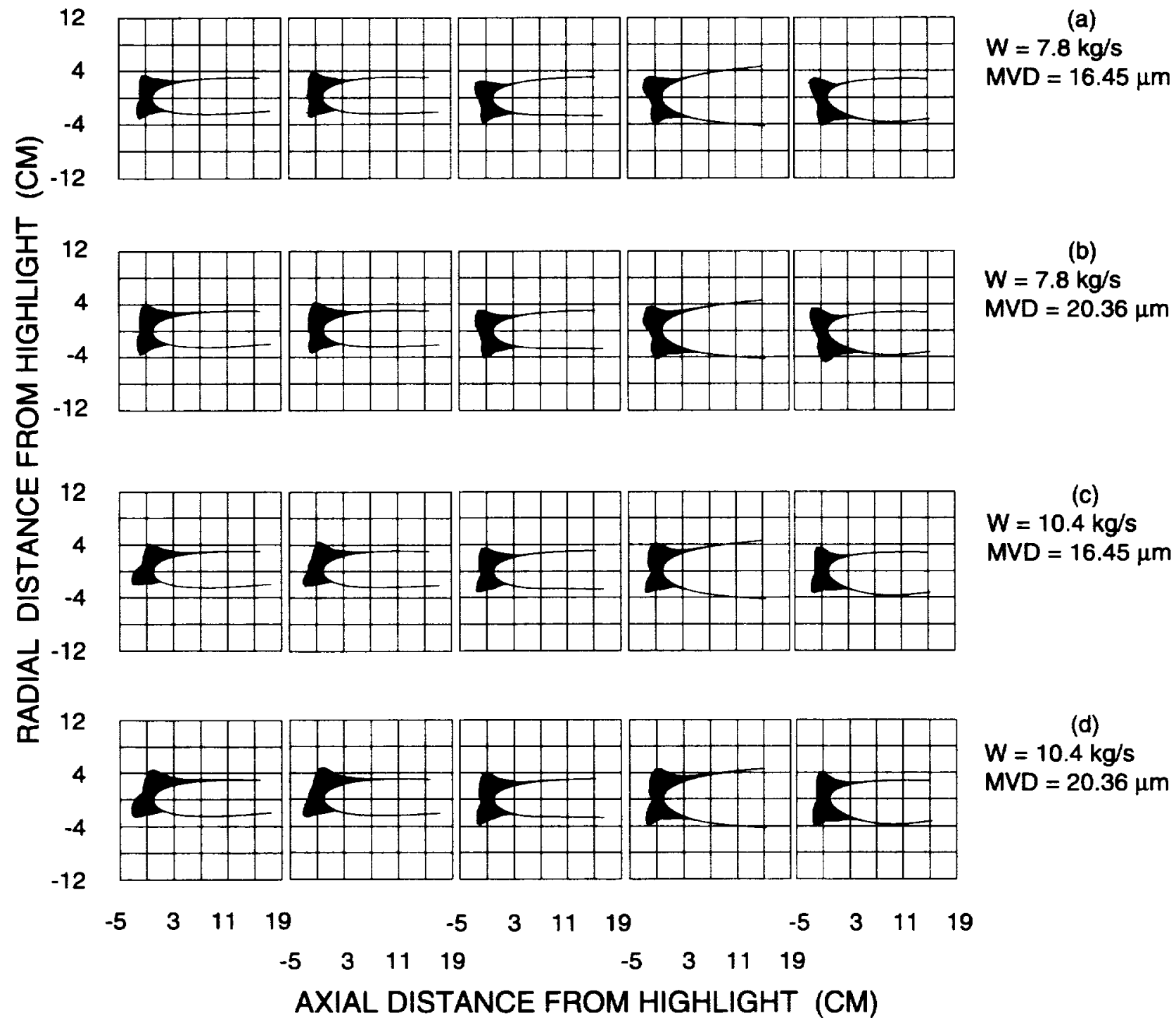

Figure 18. - Analytical ice shapes for the Boeing 737-300 inlet for $0^{\circ}$ angle-of-attack. Icing conditions: airspeed, $75 \mathrm{~m} / \mathrm{s}$; icing time, 30 minutes; static temperature, $-9.3^{\circ} \mathrm{C}$; static pressure, $95840 \mathrm{~Pa}$; liquid water content, $.695 \mathrm{~g} / \mathrm{m}^{3}$. 


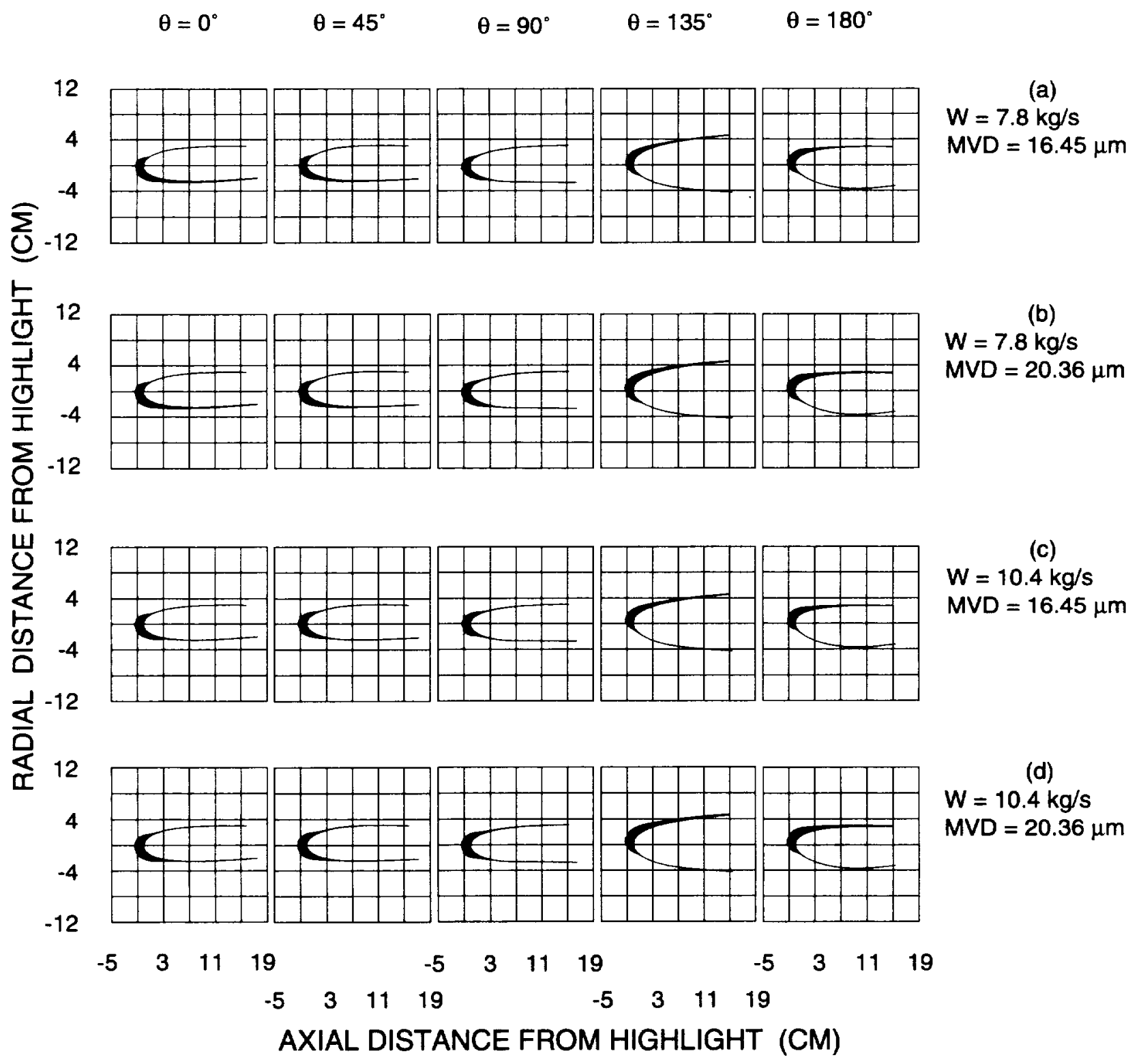

Figure 19. - Analytical ice shapes for the Boeing 737-300 inlet for $15^{\circ}$ angle-of-attack. Icing conditions: airspeed, $75 \mathrm{~m} / \mathrm{s}$; icing time, 30 minutes; static temperature, $-29.9^{\circ} \mathrm{C}$; static pressure, $95840 \mathrm{~Pa}$; liquid water content, $.2 \mathrm{~g} / \mathrm{m}^{3}$. 


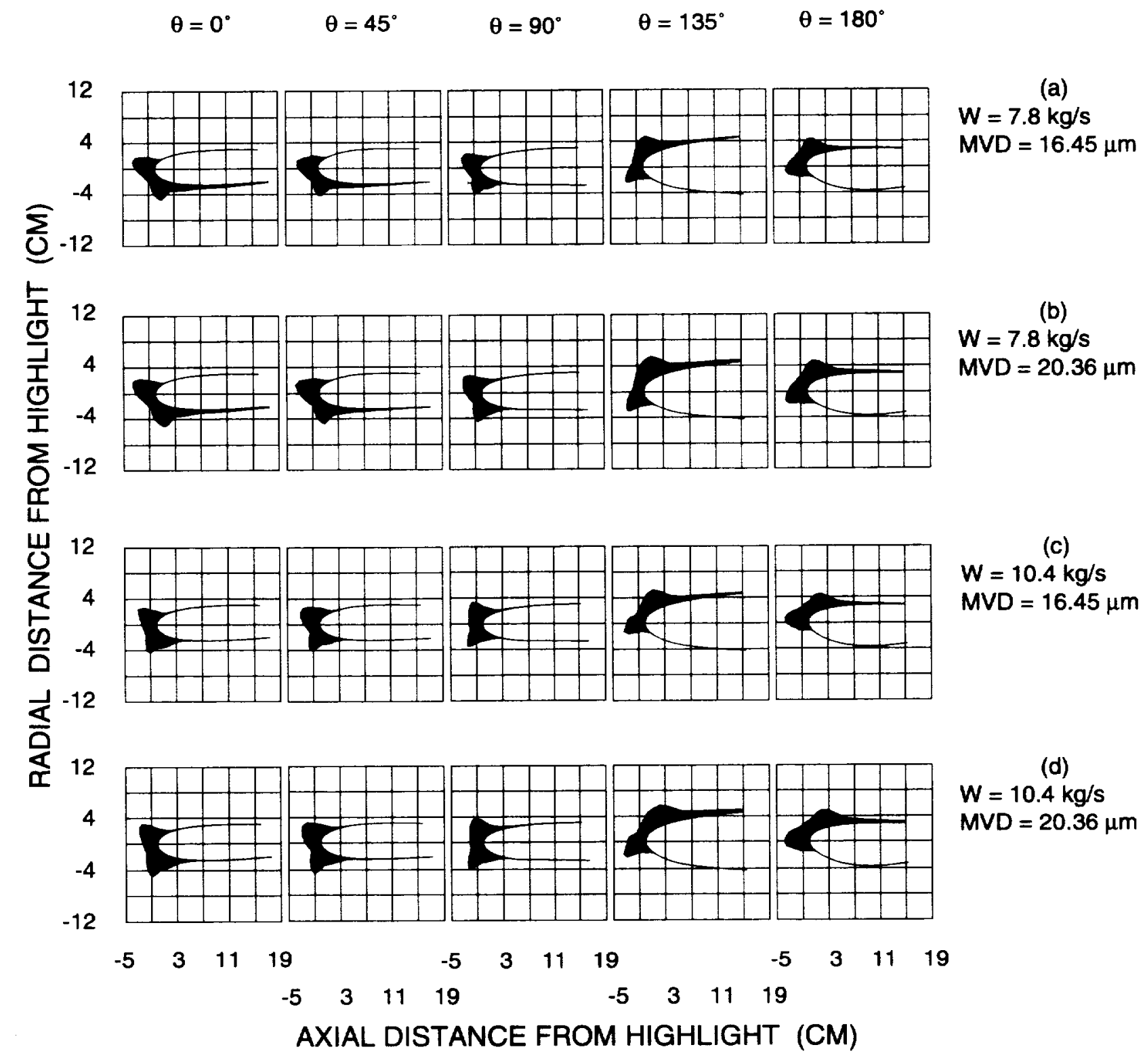

Figure 20. - Analytical ice shapes for the Boeing 737-300 inlet for $15^{\circ}$ angle-of-attack. Icing conditions: airspeed, $75 \mathrm{~m} / \mathrm{s}$; icing time, 30 minutes; static temperature, $-9.3^{\circ} \mathrm{C}$; static pressure, $95840 \mathrm{~Pa}$; liquid water content, $.695 \mathrm{~g} / \mathrm{m}^{3}$. 



\begin{tabular}{|c|c|c|c|c|c|}
\hline \multicolumn{4}{|c|}{ REPORT DOCUMENTATION PAGE } & \multicolumn{2}{|r|}{$\begin{array}{l}\text { Form Approved } \\
\text { OMB No. 0704-0188 }\end{array}$} \\
\hline \multicolumn{6}{|c|}{ 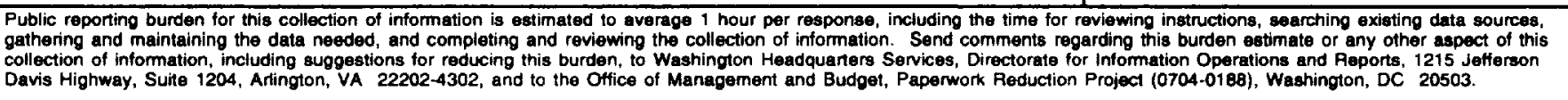 } \\
\hline \multicolumn{2}{|l|}{ 1. AGENCY USE ONLY (Leave blank) } & \multicolumn{2}{|l|}{$\begin{array}{l}\text { 2. REPORT DATE } \\
\text { February } 1997\end{array}$} & $\begin{array}{l}\text { DATE } \\
\text { chnica }\end{array}$ & $\begin{array}{l}\text { COVERED } \\
\text { Memorandum }\end{array}$ \\
\hline \multicolumn{4}{|c|}{\begin{tabular}{l|l} 
4. TITLE AND SUBTITLE & 5 \\
Collection Efficiency and Ice Accretion Calculations for a Boeing 737-300 Inlet &
\end{tabular}} & \multirow{2}{*}{\multicolumn{2}{|c|}{$\begin{array}{l}\text { 5. FUNDING NUMBERS. } \\
\text { WU-505-68-10 }\end{array}$}} \\
\hline \multicolumn{4}{|l|}{$\begin{array}{l}\text { 6. AUTHOR(S) } \\
\text { Colin S. Bidwell }\end{array}$} & & \\
\hline \multicolumn{4}{|c|}{$\begin{array}{l}\text { 7. PERFORMING OAGANIZATION NAME(S) AND ADDAESS(ES) } \\
\text { National Aeronautics and Space Administration } \\
\text { Lewis Research Center } \\
\text { Cleveland, Ohio } 44135-3191\end{array}$} & \multicolumn{2}{|c|}{$\begin{array}{l}\text { 8. PERFORMING ORGANIZATION } \\
\text { REPORT NUMBER } \\
\text { E-10498 }\end{array}$} \\
\hline \multicolumn{4}{|c|}{$\begin{array}{l}\text { 9. SPONSORINGMONTTORING AGENCY NAME(S) AND ADDRESS(ES) } \\
\text { National Aeronautics and Space Administration } \\
\text { Washington, D.C. } 20546-0001\end{array}$} & \multicolumn{2}{|c|}{$\begin{array}{l}\text { 10. SPONSORINGMONTORING } \\
\text { AGENCY REPORT NUMBER } \\
\text { NASA TM- } 107347\end{array}$} \\
\hline \multicolumn{6}{|c|}{$\begin{array}{l}\text { 11. SUPPLEMENTARY NOTES } \\
\text { Prepared for the World Aviation Congress cosponsored by the Society of Automotive Engineers and the American } \\
\text { Institute for Aeronautics and Astronautics, Los Angeles, California, October 22-24, 1996. Responsible person, Colin S. } \\
\text { Bidwell, organization code } 2720,(216) 433-3947 \text {. }\end{array}$} \\
\hline \multicolumn{4}{|c|}{$\begin{array}{l}\text { 12. DISTRIBUTIONAVAILABILITY STATEMENT } \\
\text { Unclassified - Unlimited } \\
\text { Subject Category } 02 \\
\text { This publication is available from the NASA Center for AeroSpace Information, }(301,621-0390 \text {. }\end{array}$} & \multicolumn{2}{|c|}{ 12b. DISTRIBUTION CODE } \\
\hline \multicolumn{6}{|c|}{$\begin{array}{l}\text { Collection efficiency and ice accretion calculations have been made for a Boeing 737-300 inlet using a three-dimensional } \\
\text { panel code, an adaptive grid code, the NASA Lewis LEWICE3D grid based ice accretion code. Flow solutions for the } \\
\text { inlet were generated using the VSAERO panel code. Grids used in the ice accretion calculations were generated using } \\
\text { the newly developed adaptive grid code ICEGRID3D. The LEWICE3D grid based ice accretion program was used to } \\
\text { calculate impingement efficiency and ice shapes. Ice shapes typifying rime and mixed icing conditions were generated } \\
\text { for a } 30 \text { minute hold condition. All calculations were performed on an SGI Power Challenge computer. The results have } \\
\text { been compared to experimental flow and impingement data. In general, the calculated flow and collection efficiencies } \\
\text { compared well with experiment, and the ice shapes looked reasonable and appeared representative of the rime and mixed } \\
\text { icing conditions for which they were calculated. }\end{array}$} \\
\hline \multirow{2}{*}{\multicolumn{5}{|c|}{$\begin{array}{l}\text { 14. SUBJECT TERMS } \\
\text { Ice accretion; Inlet icing; Inlet icing prediction; Inlet impingement characteristics; Inlet } \\
\text { collection efficiencies }\end{array}$}} & $\begin{array}{l}\text { 15. NUMBER OF PAGES } \\
28\end{array}$ \\
\hline & & & & & $\begin{array}{r}\text { 16. PRICE CODE } \\
\text { A03 }\end{array}$ \\
\hline $\begin{array}{l}\text { 17. SECURITY CLASSIFICATION } \\
\text { OF REPORT } \\
\text { Unclassified }\end{array}$ & & $\begin{array}{l}\text { SECUATTY CLASSIFICATION } \\
\text { OF THIS PAGE } \\
\text { Unclassified }\end{array}$ & $\begin{array}{l}\text { 19. SECURITY CLASSIFICAT } \\
\text { OF ABSTRACT } \\
\text { Unclassified }\end{array}$ & TION & 20. LIMITATION OF ABSTRACT \\
\hline
\end{tabular}

